\title{
"MULHERES DE FONTE E RIO": SOLICITAÇÃO NO CONFESSIONÁRIO, MISOGINIA E RACISMO NA BAHIA SETECENTISTA*
}

Elisangela Oliveira Ferreira**

\section{"Não saía fora de casa a procurar padres"}

Nas primeiras décadas do século XVIII, especialmente no período sagrado da Semana Santa, os devotos do sul do arcebispado da Bahia, mulheres e homens, se dirigiam à igreja matriz da freguesia de São Sebastião de Maraú, termo da vila de Camamu, seguindo o preceito católico que obrigava os fiéis ao sacramento da Confissão pelo menos uma vez ao ano, durante a Quaresma, visando à remissão dos pecados. Essa cena de busca da confissão se repetia nas demais freguesias do arcebispado da Bahia, contassem elas ou não com templos sagrados em suas povoações. Nos anos de 1718 e 1719, entre as paroquianas que buscaram o tribunal da penitência do confessionário estavam Luzia

\footnotetext{
$\mathrm{O}$ artigo circunscreve-se às duas primeiras décadas do século XVIII, correspondendo basicamente ao período de atuação do arcebispo D. Sebastião Monteiro da Vide, que esteve à frente do arcebispado da Bahia entre 1702 e 1722. As fontes inquisitoriais utilizadas nesta pesquisa são provenientes de duas séries documentais da Inquisição de Lisboa: os Cadernos do Promotor e os Cadernos de Solicitantes. Para dar maior inteligibilidade ao texto, nas citações de trechos dos documentos da época, a ortografia foi atualizada, bem como foi introduzida a pontuação, quando necessário, e desdobradas as palavras abreviadas. Agradeço ao parecerista anônimo da revista Afro-Ásia, cujas críticas e sugestões permitiram significativas melhorias no texto originalmente submetido.

** Professora da Universidade do Estado da Bahia - Campus II (Alagoinhas). E-mail: elisangela.oliferreira@gmail.com
} 
Filgueira e Úrsula das Virgens. Em um como em outro ano, essas mulheres fizeram sua confissão na quinta-feira santa, estando a serviço da fé católica em ambas as ocasiões frei Leandro Soares, religioso carmelita. ${ }^{1}$

A futura freguesia de São Sebastião de Maraú ainda era, nos primeiros anos do século XVIII, uma congregação bastante diminuta em sua sede, com uma população esparsa espalhada pelos territórios que circundavam os vários braços do rio que a batizava - o Maraú. Segundo Marcelo Henrique Dias, a capacidade desse rio de receber embarcações de maior porte, aliada à fertilidade das terras marginais, foi responsável pelo estabelecimento de fazendas dos jesuítas na região, ainda no século XVII. Nas duas margens do rio, cultivavam-se lavouras de mandioca e cana. Apesar do estabelecimento de muitos portugueses nas terras marginais ao rio, não se formou povoação antes do início do século XVIII. Maraú somente foi fundada como aldeia pelos capuchinhos em 1705, passou à condição de freguesia alguns anos mais tarde, em 1718 , e elevou-se à categoria de vila em $1758 .^{2}$

Um relato apresentado pelo vigário Pedro do Espírito Santo em 1757, às vésperas da constituição da vila, espelhou um cenário ainda relativamente acanhado. $\mathrm{O}$ foco do povoamento estava nas áreas que circundavam os braços do rio Maraú, grandes e pequenos, com seus diferentes nomes, mas a população se alojava particularmente à margem dos sete braços maiores: Caulu, Caibro, Trimembeca, Sacoira, Prategi, Aldeia Velha e Taipus. A matriz da então povoação de Maraú contava, em 1757, com 26 fogos ou domicílios, mas, em toda a freguesia de São Sebastião, haveria 1.130 pessoas de comunhão, ou seja, aquelas que deviam cumprir o preceito da confissão anual. Alguns anos mais tarde, em 1775, outro levantamento informava que na freguesia inteira

\footnotetext{
1 Arquivo Nacional da Torre do Tombo, Inquisição de Lisboa (Doravante ANTT, IL), Caderno do Promotor n. ${ }^{\circ}$ 94, fls. 13-14. <http://digitarq.dgarq.gov.pt/details?id=2318110>, acessado em: 26 jul. 2012.

2 Marcelo Henrique Dias, "Economia, sociedade e paisagens da capitania e comarca de Ilhéus no período colonial" (Tese de Doutorado, Universidade Federal Fluminense, 2007), p. 338. São Sebastião de Maraú foi uma das vinte freguesias criadas no ano de 1718 por iniciativa do arcebispo D. Sebastião Monteiro da Vide, com alvará concedido por D. João V. Cf. Cândido da Costa e Silva, Os segadores e a messe: o clero oitocentista na Bahia, Salvador: SCT/ EDUFBA, 2000, p. 56.
} 
havia 183 domicílios onde habitavam 1.823 almas. A distância entre os núcleos de moradores era de cerca de meia-légua, mas, conforme o vigário Pedro do Espírito Santo, até mesmo uma légua separava alguns deles, "quatro léguas boas" separavam a sede da freguesia de São Sebastião da sua vizinha ao norte, a de Nossa Senhora da Assunção de Camamu e, percorrendo-se outras "quatro léguas grandes" para o sul, se encontrava a freguesia de São Miguel do Rio de Contas. ${ }^{3}$

O cenário da religiosidade vivida em Maraú durante a Quaresma não era incomum na América Portuguesa. Católico que honrasse sua fé e devoção deveria cumprir, sem falta, a obrigação pascal, confessandose e comungando piedosamente, além de mostrar o respeito devido aos demais sacramentos e a cerimônias da liturgia sacra. Ainda que nem sempre fosse seguido com o fervor que se esperava, este princípio que misturava dever e devoção bem pode ter sido a força motivadora da ida das paroquianas Úrsula das Virgens e Luzia Filgueira ao templo de São Sebastião, a primeira moradora à margem do rio da Sacoira, e a segunda à margem de outro braço do Maraú, o rio do Cobi.

A tradição da Igreja dava aos fiéis o caminho da salvação por meio da confissão detalhada dos pecados. A obrigação da confissão anual, decidida pelo IV Concílio de Latrão (1215) e apresentada como instituição divina pelos teólogos desde a geração de São Tomás de Aquino, foi confirmada veementemente pelo Concílio de Trento (1545-1563). Com isso, ampliou-se o poder e o território do confessor, que se viu transformado em especialista de casos de consciência. Sendo a doutrina da penitência institucionalizada como um sacramento necessário e indispensável à vida cristã, o sacerdote tornou-se uma espécie de distribuidor da misericórdia de Deus, o canal através do qual agia toda a

\footnotetext{
"Relação das Povoações e sítios que contém o rio do Marahú, districto da freguesia de São Sebastião e moradores della, no Arcebispado da Bahia, pello vigário collado Pedro do Espirito Sancto". Annaes da Bibliotheca Nacional do Rio de Janeiro, v. 31 (1913), p. 190, < http:// objdigital.bn.br/acervo_digital/anais/anais_031_1909.pdf>, acessado em 19 fev. 2013; "Mappa de todas as Freguezias que pertencem ao Arcebispado da Bahia e sugeitos os seus habitantes no temporal ao governo da mesma Bahia, com a distincção das comarcas e villas a que pertecem, com o numero de fogos e almas, para se saber a gente que se pode tirar de cada uma dellas para o serviço de S.M., sem opressão dos povos". Annaes da Bibliotheca Nacional do Rio de Janeiro, v. 32 (1914), p. 289, <http://objdigital.bn.br/acervo_digital/anais/ anais_032_1910.pdf>, acessado em 19 fev. 2013.
} 
Igreja. Só ele poderia conceder a absolvição, que era a fonte direta de

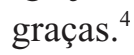

Ao mesmo tempo, a confissão desenvolveu nos fiéis a cultura do exame de consciência. Jean Delumeau analisa o poder de culpabilização das consciências e dos comportamentos individuais posto em ação pelo ato confessional. $\mathrm{O}$ silêncio voluntário no confessionário, provocado, muitas vezes, pela vergonha de confessar pecados de ordem sexual, muito preocupou a Igreja. Uma verdadeira pastoral do medo foi utilizada em sua obsessão de alcançar a confissão exata de todos os pecados, inclusive os do sexo, incutindo nos fiéis a ideia de que somente a confissão completa forneceria o caminho da salvação. As confissões sacrílegas, com ocultação de pecados graves, levariam às comunhões indignas. ${ }^{5}$

Michel Foucault também discute como a reforma católica se dedicou a acelerar o ritmo da confissão anual e tentou impor regras meticulosas de exame de si mesmo, atribuindo cada vez mais importância, na penitência, a todas as insinuações da carne, do ato sexual em si às inquietações do desejo. Mesmo policiando-se a língua, procurando-se não interrogar as questões sexuais tão abertamente como ensinavam os manuais de confessores da Idade Média, a extensão da confissão, relacionada à carne, não pararia de crescer, afirma Foucault. "Uma dupla evolução tende a fazer, da carne, a origem de todos os pecados e a deslocar o momento mais importante do ato em si para a inquietação do desejo, tão difícil de perceber e formular". ${ }^{6}$ A pastoral católica, com o incitamento da confissão de todos os pecados, inscreveu também "como dever fundamental, a tarefa de fazer passar tudo o que se relaciona com o sexo pelo crivo interminável da palavra".

No Brasil Colônia, chamava-se comumente de desobriga o cumprimento pelos fiéis católicos do preceito da confissão anual durante a

\footnotetext{
4 Jean Delumeau, O pecado e o medo: a culpabilização no Ocidente (séculos 13-18), v. 1, Bauru, SP: EDUSC, 2002, p. 339; Luiz Mott, "Cotidiano e vivência religiosa: entre a capela e o calundu", in Laura de Mello e Souza (org.), História da vida privada no Brasil: cotidiano e vida privada na América Portuguesa (São Paulo: Companhia das Letras, 1997), pp. 210-1.

5 Delumeau, O pecado e o medo, v. 2, p. 273.

6 Michel Foucault, História da sexualidade: a vontade de saber, Rio de Janeiro: Graal, 1988, p. 26.

Foucault, História da sexualidade, p. 27.
} 
Quaresma. A palavra também denotava a ação do sacerdote que, nessa época, comparecia às comunidades para desobrigar os fiéis de seus pecados, ministrando-lhes o sacramento da Penitência. Com o tempo, o seu significado ampliou-se para designar o giro dos párocos pelas comunidades em qualquer época do ano. ${ }^{8}$

Supõe-se que, para muitas mulheres dos tempos coloniais, a iniciativa de se desobrigar dos pecados, de desvelar suas intimidades e confessar suas culpas não fosse uma tarefa fácil. Para aquelas duas mulheres de Maraú, particularmente, tudo indica que o episódio da confissão não foi um acontecimento habitual e tranquilo. Em uma devassa empreendida nas vilas do sul da Bahia, em 1719 ou nos primeiros meses de 1720, encontravam-se Luzia Filgueira e Úrsula das Virgens a relatar ao reverendo visitador as desventuras vividas no confessionário, sob a autoridade do carmelita frei Leandro Soares. Luzia Filgueira declarou que ele "a solicitara na confissão dizendo-lhe as palavras seguintes: "Tu queres ter alguma coisa comigo?", ao que ela respondeu negativamente. ${ }^{9}$ Em outro depoimento, prestado ao comissário do Santo Ofício na capital da Bahia, Luzia salientou que "indo ela testemunha confessar-se com o dito padre frei Leandro, este a solicitara para dormir com ele e ter cópula carnal no mesmo ato da confissão sacramental". ${ }^{10}$ Na Quaresma de 1719, a sedução do mesmo religioso recaíra sobre Úrsula das Virgens, que assim relatou ao visitador encarregado da diligência em Maraú o diálogo estabelecido com ele no confessionário:

[...] estando ela testemunha aos seus pés a solicitou e acometeu com instâncias para com ela ter cópula carnal, dizendo-lhe as palavras seguintes: tu queres dormir comigo? Vai a minha casa a noite, e dormirás comigo. Ao que ela testemunha respondeu que não saía fora de casa a procurar padres. ${ }^{11}$

\footnotetext{
8 Heitor Araújo, Vinte anos de sertão, Bahia: Imprensa Gráfica Limitada, 1953; Lycurgo Santos Filho, Uma comunidade rural do Brasil antigo: aspectos da vida patriarcal no sertão da Bahia nos séculos XVIII e XIX, São Paulo: Nacional, 1956, p. 187; Cândido da Costa e Silva, Roteiro da vida e da morte: um estudo do catolicismo no sertão da Bahia, São Paulo: Ática, 1982, p. 20.

ANTT, IL, Caderno do Promotor n. ${ }^{\circ}$ 94, fl. 6.

10 ANTT, IL, Caderno do Promotor n. ${ }^{\circ}$ 94, fl. 13.

11 ANTT, IL, Caderno do Promotor n. ${ }^{\circ} 94$, fl. 6.
} 
Estabelecia-se, assim, o chamado crime de solicitação (solicitatio ad turpia), quando os sacerdotes incorriam no assédio às suas filhas espirituais no próprio confessionário. $\mathrm{O}$ delito era considerado uma subversão grave do sacramento da Penitência e da própria condição clerical, combatido pela Igreja por meio do Santo Ofício. ${ }^{12}$ Utilizando a confissão como veículo de sedução e satisfação dos desejos sexuais, esses religiosos transformavam-se de condutores da fé e da salvação em agentes do pecado, e o confessionário, espaço destinado ao perdão divino, convertia-se em templo da luxúria. Virava-se mesmo ao avesso o sentido da confissão. Ela era um mecanismo essencial do controle da Igreja sobre as atitudes, os comportamentos, os pensamentos e os desejos dos fiéis, mas, quando convertida em veículo de satisfação sexual do próprio confessor, essa função ficava completamente deturpada. ${ }^{13}$

Voltando ao caso do sedutor de Maraú, também no que se refere à sua vida pública, longe do território da confissão, o carmelita não era exatamente um guardião da imagem de castidade clerical pregada pelo catolicismo. Além de andar por Maraú posando de secular, sem o hábito, frequentemente "com uma espingarda nas costas, passarinhando", para onde quer que fosse levava consigo duas mulheres negras, uma delas sempre mantida em sua casa, com a qual "tinha trato ilícito". ${ }^{14} \mathrm{~A}$ informação foi dada por Luzia Filgueira e, se confirmada, agravava a situação do frade, tendo em vista que ele incorria não somente no crime de solicitação, da alçada da Inquisição, mas também no de concubinato, sendo um clérigo, de competência do juízo eclesiástico.

Havia ainda outra acusação contra frei Leandro Soares de uma paroquiana da capital, Maria da Purificação, 25 anos, solteira, filha de Úrsula da Conceição e enteada de José Álvares, mercador de lojas, em companhia dos quais morava na Calçada do Carmo. O desenredo de

\footnotetext{
$12 \mathrm{O}$ crime de solicitação nem sempre foi da alçada inquisitorial, pertencendo antes à Justiça eclesiástica, exercida pelos bispos e seus vigários, mas, progressivamente, esse e outros delitos foram sendo deslocados para o tribunal do Santo Ofício, instalado em Portugal em 1536. Lana Lage da Gama Lima, "A confissão pelo avesso: o crime de solicitação no Brasil colonial” (Tese de Doutorado, Universidade de São Paulo, 1990), p. 67.

13 Ronaldo Vainfas, Trópico dos pecados: moral, sexualidade e Inquisição no Brasil, Rio de Janeiro: Nova Fronteira, 1997, p. 207.

14 ANTT, IL, Caderno do Promotor n. ${ }^{\circ}$ 94, fl. 6.
} 
Maria da Purificação com o frade ocorreu na Quaresma de 1717, antes, portanto, dos casos de Maraú, quando ela foi confessar-se na "capela dos terceiros de Nossa Senhora do Monte do Carmo". A solicitação, conforme a moça, ocorrera da seguinte maneira: "depois de lhe dizer os seus pecados, ainda antes da absolvição, lhe falou o dito padre frei Leandro na forma seguinte: Adonde mora vosmecê? Quem são seus pais? Quer vosmecê ser meus amores?". Ela contou que nada respondera e, então, ele a havia absolvido. Mas não terminou aí. Logo depois da saída de Maria do confessionário, foram "confessar-se com o dito padre duas escravas dela denunciante, a saber, Inácia, do Gentio da Mina, já defunta, e Maria, do Gentio de Angola". Entendendo que eram escravas de Maria, perguntara o frade a ambas "quem era ela e adonde morava, e com efeito pela dita escrava Inácia, já defunta, mandou o dito padre frei Leandro a ela denunciante três ou quatro escritos de amores". ${ }^{15}$

Maria da Purificação ainda acrescentou que, voltando certo tempo depois em companhia de sua mãe à mesma capela dos terceiros, onde costumavam ouvir missas, ambas observaram que o frade confessava apenas os homens. Outra devota que se encontrava na igreja informou à mãe dela que "a causa do dito padre não confessar mulheres ouvira dizer que fora pelo seu prelado o suspender desse exercício, pelas solicitações que no confessionário fazia". ${ }^{16}$ A suspensão temporária ou permanente do direito de confessar era um dos castigos atribuídos aos religiosos acusados do crime de solicitação. Tudo indica que foi depois dessa suspensão que frei Leandro Soares se retirou para a região de Camamu, onde continuou desafiando os preceitos de sua condição de clérigo.

\section{"De todo o serviço de porta a fora"}

Como demonstra Ronaldo Vainfas, as linhas de força do colonialismo imprimiram suas marcas nas relações amorosas do passado. ${ }^{17}$ Nos registros da

\footnotetext{
15 No documento, há abreviações que foram aqui desdobradas. A grafia original aparece da seguinte forma: “[...] Adonde mora VM? [...] Quer VM ser meos amores?”. ANTT, IL, Caderno do Promotor, $\mathrm{n}^{\circ}$ 94, fl. 39.

16 ANTT, IL, Caderno do Promotor nº 94, fl. 39.

17 Ronaldo Vainfas, "Moralidades brasílicas: deleites sexuais e linguagem erótica na sociedade escravista", in Laura de Mello e Souza (org.), História da vida privada no Brasil: cotidiano e vida privada na América portuguesa (São Paulo: Companhia das Letras, 1997), p. 270.
} 
Inquisição, os exemplos dos solicitantes iluminam não somente um território da sedução e da busca do prazer, um abrigo dos amantes erigido dentro do próprio seio da Igreja, mas a sujeição que acometia muitas mulheres na situação mais privada e secreta que poderia existir. Também iluminam a desqualificação recorrente a que muitas delas eram submetidas. Isso ficou evidente já nesses episódios em que são personagens Luzia Filgueira, Úrsula das Virgens e o carmelita frei Leandro Soares.

$\mathrm{Na}$ apuração das culpas em matéria de solicitação pelo Santo Ofício, era realizada uma verdadeira devassa, e não somente sobre a vida do religioso acusado, mas, particularmente, sobre o comportamento das mulheres que denunciavam. Nesse caso do frade carmelita e suas paroquianas, após aquelas primeiras denúncias, feitas durante a visitação na freguesia de Maraú, seguiu-se uma segunda inquirição das mesmas mulheres, em janeiro de 1721, já na capital da Bahia. No mesmo período, houve todo um repertório de apuração do crédito das envolvidas no episódio. Conforme consta nos documentos, convinha "ao serviço de Deus Nosso Senhor, e bem da justiça do Santo Ofício" constatar se as depoentes eram pessoas de bom procedimento, reputação e verdade. ${ }^{18}$

No momento do testemunho perante a mesa inquisitorial, além do comissário e do escrivão, também se exigia a presença de dois outros membros do Santo Ofício, que deveriam ser "honestas e eclesiásticas pessoas" encarregadas de atestar, após a saída da testemunha, se o que ela denunciava parecia ser verdadeiro. ${ }^{19}$ No caso de Luzia Filgueira, assistiram a seu depoimento os padres Alberto Ferreira da Silva, notário do Santo Ofício, e Caetano Correia Botelho, beneficiado na Santa Sé da Bahia e nela coadjutor. A opinião deles é um indício do nível de desqualificação que poderia atingir as mulheres envolvidas em denún-

\footnotetext{
18 No primeiro regimento da Inquisição, de 1552, já se enfatizava a necessidade de se verificar a qualidade e o crédito das testemunhas. No seu Capítulo 21 consta: “Assim mesmo se olhará muito a qualidade das testemunhas e o crédito que lhe deve dar segundo a qualidade do caso, e os inquisidores farão diligência sobre o crédito que devem dar às testemunhas antes que procedam a prisão e negócio de tanta importância se requer e o mesmo se farão em todas as mais testemunhas que perguntarem". "Regimento da Santa Inquisição - 1552", Revista do $I H G B$, v. 157 , n. 392 (1996), p. 580.

19 Este era o procedimento de rotina nas diligências do Santo Ofício, já previsto desde o primeiro regimento, e continuamente verificado na documentação inquisitorial. "Regimento da Santa Inquisição - 1552", p. 586.
} 
cias de solicitação. Perguntado aos mesmos se lhes parecia que Luzia falava a verdade e merecia crédito,

[...] foi dito por eles que visto o ruim feitio da dita testemunha, por ser uma testemunha, digo, mestiça feia, lhes parecia ser com segunda intenção e menos verdade o que a dita testemunha asseverava, e dizia, pois não era crível sendo a dita testemunha tal como era sucedesse o fato relatado. ${ }^{20}$

Aqui aparecem dois componentes da desqualificação da denunciante: ela era feia e, mais que isso, era mestiça. Por ser uma mestiça feia, concluíram os religiosos, era improvável que Luzia representasse alguma tentação à libido do acusado. Sua denúncia, portanto, não poderia ser verdadeira.

O descrédito dos sacerdotes que avaliaram o depoimento de Luzia Filgueira não representava uma exceção. A desqualificação de origem racial se tornava clara quando se tratava de conferir crédito às mulheres que denunciavam a solicitação, conforme Lana Lage Lima. ${ }^{21}$ A fala dos padres não nos permite identificar, à primeira vista, outro componente bastante agravante no pensamento hierárquico da época que certamente influiu na avaliação estigmatizada dos clérigos em questão. Luzia Filgueira era uma escrava. Era propriedade do lavrador Manoel Gonçalves Campos, morador às margens do rio do Cobi, em Maraú. Cativa também era a condição de Úrsula das Virgens, que vivia às margens do rio da Sacoira, em Maraú, em casa de seu senhor Pedro Vaz Lemos, e caracterizada, ao longo do processo, às vezes como parda, outras como mulata, sendo esta última a designação mais recorrente.

Durante o período colonial, houve uma grande flutuação de significados para termos que apontavam uma classificação baseada na mestiçagem. "Se o século XVII anuncia a nossa etnogênese, o século XVIII em muito apontará e consolidará um dos nossos dilemas: a ambiguidade classificatória", diz Jocélio Teles dos Santos. ${ }^{22}$ A incerteza na classificação de Úrsula das Virgens nos documentos não deixa de ser

\footnotetext{
20 ANTT, IL, Caderno do Promotor n. ${ }^{\circ}$ 94, fl. 13 (grifos meus).

21 Lima, "A confissão pelo avesso", p. 653.

22 Jocélio Teles dos Santos, "De pardos disfarçados a brancos pouco claros: classificações raciais
} 
reveladora. Silvia Hunold Lara demonstra que, apesar de os termos "pardo" e "mulato" aparecerem como equivalentes na acepção do dicionarista Rafael Bluteau, no uso geral havia uma evidente diferença de conotação. O termo "pardo" poderia assumir uma forma mais neutra, talvez por ter seu significado mais descritivo, associado a uma cor situada entre "branco e preto". Nos usos coloniais, insiste a autora, ele ganhava um significado bem menos pejorativo que "mulato". ${ }^{23}$ É também reveladora a insistência na condição de mestiça de Luzia Filgueira. Ao longo do processo, seu sobrenome pouco foi mencionado, o que não aconteceu com Úrsula das Virgens. Ela era simplesmente "Luzia mestiça", e o qualificativo de "mestiça" poderia designar diversas misturas, "inclusive as de difícil discernimento colonial". ${ }^{24}$ Chama a atenção também o fato de que, no caso de Maria da Purificação, a moça assediada em Salvador, não se fez menção em momento algum à sua cor, o que sugere que ela seria branca ou tida com tal. Adjetivar era na época tanto ou mais do que descrever, era classificar socialmente. ${ }^{25}$

Os mesmos sacerdotes do caso de Luzia Filgueira julgaram se Úrsula das Virgens merecia ou não crédito. Apesar de carregarem menos na tinta do preconceito no quesito da aparência, não deixaram de lhe imputar dúvidas, tanto pela condição de cativa quanto por uma possível ligação e trama com Luzia Filgueira:

[...] e por eles foi dito que enquanto ao jeito da dita testemunha, algum crédito merecia o seu depoimento. Mas que como era pessoa de baixa sorte e servil condição, e era da mesma freguesia da primeira testemunha, Luzia mestiça, lhes parecia que poderiam vir ajustadas e calcadas para esse juramento. ${ }^{26}$

no Brasil dos séculos XVIII-XIX”, Afro-Ásia, v. 32 (2005), p. 119. Em pesquisa realizada na documentação da Santa Casa de Misericórdia da Bahia, este autor concluiu que os termos "negro", "mulato" e "crioulo" já eram utilizados no século XVII, em testamentos dos senhores que deixavam doações, e esses termos de classificação indicavam tanto a condição social quanto uma marca da "cor". Santos, "De pardos disfarçados", p. 117.

23 Silvia Hunold Lara, Fragmentos setecentistas: escravidão, cultura e poder na América portuguesa, São Paulo: Companhia das Letras, 2007, pp. 141-2.

24 Santos, "De pardos disfarçados", p. 119.

25 João de Figueirôa-Rêgo e Fernanda Olival. "Cor da pele, distinções e cargos: Portugal e espaços atlânticos portugueses (séculos XVI a XVIII)”. Tempo, v. 16, n. 30 (2011), p. 117, <http:/ /www.scielo.br/pdf/tem/v16n30/a06v16n30.pdf>, acessado em 18 fev. 2013.

26 ANTT, IL, Caderno do Promotor n. ${ }^{\circ}$ 94, fl. 14. 
Aqui, além da desconfiança relacionada com a condição social, também aparecem rastros do discurso misógino da modernidade cristã que via as mulheres como traiçoeiras e naturalmente inclinadas para a mentira, para a leviandade. Para a maioria dos homens da Renascença, conforme Jean Delumeau, "a mulher é no mínimo suspeita e no mais das vezes perigosa". ${ }^{27}$ Esse pensamento ainda permeava o século XVIII e, também, as terras coloniais. Por essas paragens, quando se levava em consideração o fator da mestiçagem, a tendência era exacerbá-lo.

A Inquisição cuidou de perseguir as seduções praticadas pelos padres no refúgio do confessionário, considerando o crime de solicitação um delito grave, assimilável à heresia pela suspeita que pesava sobre os solicitantes de "sentirem mal do sacramento da penitência", e insistindo para que a população denunciasse os transgressores. ${ }^{28}$ No entanto, é possível deduzir-se que nem sempre era fácil para as mulheres assediadas denunciarem seus confessores. $\mathrm{O}$ ato de denúncia não raro se dava muito tempo depois, por vezes quando o solicitante já não mais se encontrava servindo na freguesia, ou já havia até falecido. Dizer que não sabia que tinha obrigação de denunciar a solicitação ao Santo Ofício era um argumento comum usado pelas mulheres para justificar o silêncio prolongado. Também era recorrente alegar a ausência de comissários na região para formalizar a queixa, sobretudo quando se tratava de casos ocorridos em regiões distantes da capital e das sedes episcopais.

Sem desconsiderar completamente essas explicações, pode-se suspeitar, em relação ao silêncio, também o medo que as mulheres sen-

\footnotetext{
27 Jean Delumeau, História do medo no Ocidente, 1300-1800: uma cidade sitiada, São Paulo: Companhia das Letras, 2009, p. 522.

28 Conforme Lana Lage Lima, a jurisdição do Santo Ofício sobre os solicitantes, expressa no regimento inquisitorial de 1613 , se deu pela suspeita que contra eles pesava "de sentirem mal do sacramento da penitência" e, portanto, a "legitimidade do foro inquisitorial sobre esses delitos implicava sua assimilação à heresia". Ronaldo Vainfas também argumenta que, em matéria de crimes de ordem moral, como a solicitação, o que o Santo Ofício perseguia era a presunção de "má doutrina" e não a transgressão moral e sexual em si mesma. No entanto, dificilmente um solicitante processado reconhecia "sentir-se mal" da Igreja e seus sacramentos. As contingências da vida cotidiana, exacerbadas pela fragilidade da carne ou pela tentação do demônio, eram os verdadeiros motivos alegados por padres envolvidos no crime de solicitação. Cf. Lima, “A confissão pelo avesso", p. 72-3; Vainfas, Trópico dos pecados, p. 201; Vainfas, "Moralidades brasílicas", p. 260.
} 
tiam de pronunciarem-se sobre o ocorrido, de terem seus relatos contestados ou negados, de serem mesmo rechaçadas na comunidade por conta da própria teia de proteção e cumplicidade em que esses homens da Igreja estavam enredados. Além do medo, por parte de muitas delas havia também a vergonha de confessar faltas, voluntárias ou não, relacionadas com os pecados da carne. A proteção da honra e da virtude levava muitas mulheres ao silenciamento sobre os desvios dos padres confessores. Diversas mulheres somente faziam as denúncias após a admoestação de algum confessor zeloso ou mais firme na sua vocação. Era comum elas ficarem impedidas de participar do sacramento da Eucaristia, por ordem do novo confessor, enquanto encobrissem a atitude do outro vigário cobiçoso, não importando há quanto tempo a solicitação havia ocorrido. Muitas aproveitavam a visita de missionários, que se deslocavam pelas freguesias pregando missões, para denunciar seus vigários solicitantes.

No entanto, deve ser considerada também a visão que a população em geral tinha sobre os desvios morais dos clérigos. Numa terra em que os encontros fortuitos e casuais eram bastante comuns, e o concubinato era generalizado, é bem possível que os amores de padres não causassem tanto estranhamento. Segundo Lana Lima, mesmo com relação aos solicitantes, cujo crime era mais condenável que o concubinato de um clérigo, por macular de modo explícito um sacramento, tudo leva a crer que os fiéis não viam como um crime tão grave, passível de punição pelo Santo Ofício. A autora observou que a esmagadora maioria das mulheres denunciantes desconhecia a obrigação de denunciar, até ser alertada por outro confessor. Isso explica também o motivo de muitos casos terem sido denunciados passados muitos anos da ocorrência da solicitação. $^{29}$

No episódio das escravas de Maraú, ficou claro que a decisão de tornar público o assédio do frei Leandro Soares não partiu das envolvidas, e menos ainda de Luzia Filgueira, que se viu enredada nas teias da Inquisição porque o seu senhor tomou a iniciativa de formalizar a denúncia. Percebe-se mesmo uma Luzia descontente com o desenrolar

${ }^{29}$ Lima, "A confissão pelo avesso", pp. 348-9. 
dos acontecimentos. Uma testemunha chamada Teodora Garcez da Silva, moradora na capital, que abrigou as duas mulheres por três ou quatro dias, enquanto lá estiveram à disposição do Santo Ofício, reforça a impressão de que Luzia Filgueira participou, de certo modo, do processo coagida pela denúncia do seu senhor e pelo poder da Inquisição. Conforme Teodora Garcez:

[...] chegando a casa dela testemunha a dita Luzia mestiça, lhe perguntara ela testemunha que causa a trazia a esta cidade, e que a dita Luzia mestiça lhe respondera que não sabia o para que, mas que só o ser chamada por parte do Santo Ofício, e que de tudo tinha o seu senhor culpa. ${ }^{30}$

O descontentamento de Luzia Filgueira com os rumos da denúncia se manifestou desde o princípio. Manoel Martins, morador em Maraú e compadre de uma filha de Luzia, também chamado a depor sobre o crédito das escravas, disse que havia sete meses, estando ele na casa de Manoel Gonçalves Campos, senhor de Luzia, com ela também presente nessa ocasião em que se comentava a prisão recente do frei Leandro Soares, a escrava teria dito que o "seu senhor tinha toda a culpa de todo o sucedido". Conforme Manoel Martins, ela ainda reforçou sua opinião sobre o caso com as seguintes palavras: "porque a mim me não cansam coisas do padre frei Leandro, ou o que tinha eu com ele". ${ }^{31}$ A declaração sugere, por um lado, que aquela não era a primeira vez que frei Leandro lançava sobre Luzia suas conversações e jogos eróticos e, por outro, que ela sabia como lidar com os convites do sedutor de batina, fosse negando ou aceitando as suas investidas, não se aborrecendo com sua atitude. Por trás do crime de solicitação não raro também havia cumplicidades, o que pode ter sido o caso dos dois. Além de espaço para o assédio unilateral, iniciativa de confessores afoitos, o confessionário também serviu de templo para amores sacrílegos, de refúgio para os prazeres clandestinos. Desenrolavam-se namoros que tinham nele o palco principal.

As diligências sobre o crédito e a conduta de Luzia Filgueira e Úrsula das Virgens não ficaram somente na opinião dos padres ratifica-

30 ANTT, IL, Caderno do Promotor n. ${ }^{\circ}$ 94, fl. 20.

31 ANTT, IL, Caderno do Promotor n. ${ }^{\circ}$ 94, fl. 20. 
dores. No ritual da Justiça inquisitorial, era necessário ainda juntar-se ao processo uma gama de testemunhas, invariavelmente do sexo masculino, que deviam conhecer de alguma forma as envolvidas e compareciam para depor ao Santo Ofício sobre o comportamento, a reputação e o crédito das mulheres. Seis homens narraram pormenores sobre a vida das escravas de Maraú, e essas narrativas muito dizem sobre as regras de conduta feminina, que simbolizavam a própria moral vigente na época, e a tentativa de adestramento que incidia sobre as mulheres.

A primeira dessas regras dizia respeito aos espaços da casa e da rua. As mulheres da Colônia foram domesticadas dentro de um modelo que as valorizava como senhoras de único espaço: o doméstico. Obviamente, esse era o modelo ideal, o padrão da moralidade almejada. $\mathrm{O}$ outro, a rua, era o espaço de infração da norma, da transgressão. Muitas mulheres, por inclinação ou necessidade, atravessavam os limites dessa fronteira ideal e, por esse desvio, sofriam as recriminações sociais. Percebe-se o embate de um modelo que se aproxima dessa dicotomia da casa e da rua claramente exposto nos depoimentos sobre o comportamento dessas duas escravas de Maraú. O mestre de uma embarcação que navegava para a vila de Camamu, chamado Manoel, 75 anos, disse o seguinte sobre Luzia Filgueira:

Ao que tocava a Luzia mestiça, sabia por ouvir geralmente que era mulher pública e servia a seu senhor de fonte e rio, e de todo o mais serviço, porém que lhe parecia poderia em parte dar-lhe crédito ao que dizia, e em parte não pela qualidade da pessoa, mas que também não sabia que a dita mestiça fosse acostumada a dizer mentira nem levantar falso testemunho a ninguém. ${ }^{32}$

Sobre a mulata Úrsula das Virgens, o barqueiro Manoel disse que sabia também "por ouvir geralmente" que ela "era mulher do trato, mas que o fazia com cautela pelas vexações e apertos em que a punha o dito seu senhor". ${ }^{33}$ Mas, apesar da má fama que corria sobre sua reputação, Manoel afirmou que, pelo longo conhecimento que dela tinha, the parecia que às suas palavras se podia dar crédito, em juízo e fora dele.

32 ANTT, IL, Caderno do Promotor n. ${ }^{\circ}$ 94, fl. 18 (grifo meu).

33 ANTT, IL, Caderno do Promotor n. ${ }^{\circ}$ 94, fl. 18. 
A expressão "mulher do trato", conforme o dicionarista setecentista Antônio de Morais Silva, era um dos significados de "meretriz", que na sua definição era também: "a mulher que devassa a sua honestidade por mau preço", ou ainda "puta, mulher dama, marota, porca, rameira", entre outras. Antes dele, Raphael Bluteau, que não mencionou a expressão "mulher do trato", definiu "meretriz" como "Mulher que faz mercê; Mulher pública; Mulher prostituta e posta ao ganho". ${ }^{34}$ Os homens setecentistas chamados a falar sobre suas vizinhas de Maraú certamente usavam as expressões "mulher do trato" ou a equivalente "mulher pública" na mesma acepção atribuída pelos dicionaristas a termos sinônimos, a exemplo de "meretriz". O significado era claramente de cunho sexual e pejorativo.

Outro proprietário de uma embarcação, José da Silva, 35 anos, asseverou que Luzia Filgueira e Úrsula das Virgens eram mulheres públicas, acrescentando que a primeira servia "ao seu senhor de fonte e rio e todo o mais serviço de portas a fora", pelo que concluía que não se poderia dar muito crédito ao que ela dizia. Quanto à segunda, sua narrativa corrobora, até certo ponto, a impressão, deixada pelo primeiro depoente, de que a escrava vivia sob a vigilância mais cerrada e constante de seu senhor:

[...] a mulata Úrsula, posto que seja mulher pública, contudo não sai fora às vezes que quer, porque o dito seu senhor lhe impede, e se ocupa em fazer rendas e no mais serviço da casa; e que a esta dita Úrsula das Virgens se podia dar mais crédito em juízo e fora dele por ser segura e verdadeira no seu dizer e pela boa criação e educação que teve dos ditos seus senhores. ${ }^{35}$

Esses depoimentos foram ouvidos na própria Maraú, quando se processava a primeira diligência sobre os abusos do frei Leandro Soares, que já se encontrava preso no seu convento do Carmo, na capital,

\footnotetext{
${ }^{34}$ Antonio de Moraes Silva. Diccionario da lingua portugueza: recompilado dos vocabularios impressos ate agora, e nesta segunda edição novamente emendado e muito acrescentado, por ANTONIO DE MORAES SILVA, Lisboa: Typographia Lacerdina, 1789, p. 292; Raphael Bluteau, Vocabulario Portuguez \& Latino: aulico, anatomico, architectonico..., Coimbra: Colégio das Artes da Companhia de Jesus, 1712-1728, p. 437, <http://www.brasiliana.usp.br/ dicionario/>, acessado em 19 fev. 2013.

35 ANTT, IL, Caderno do Promotor n. ${ }^{\circ}$ 94, fl. 18.
} 
aguardando o desenrolar do processo. Outras quatro testemunhas foram ouvidas na Cidade da Bahia perante a comissão do Santo Ofício. Em suas falas, fica igualmente evidente a desqualificação das duas escravas de Maraú. Os quatro homens eram naturais de Portugal, e esse padrão de escolha foi recorrente em matéria de informantes sobre o crédito e a reputação das mulheres envolvidas nos casos de solicitação. Pedro Soares Maciel, 50 anos, dono de uma loja em Maraú, disse que conhecia as duas mulheres havia oito ou nove anos, e que elas "tinham mau procedimento por serem mulheres do mundo e do trato, como era notório em toda aquela freguesia". Se elas eram mentirosas ou verdadeiras, no entanto, disse que não sabia. Antônio de Seixas Portela, 32 anos, mestre de uma sumaca dos padres da Companhia de Jesus que navegava o rio Maraú, também afirmou que ambas eram "mulheres de baixa sorte", que tratavam "com todo o gênero de pessoas, usando mal de si" e, por conta desse mau proceder, lhe parecia que não mereciam crédito. Manoel Martins, 21 anos, também julgava que "por suas qualidades e condições" não se devia dar crédito às palavras das duas mulheres, apesar de reiterar, como os outros depoentes, que não sabia que fossem acostumadas a levantar falso testemunho. Quanto a seu comportamento, seguiu o padrão da fala de seus vizinhos de Maraú: "Disse que as ditas Luzia mestiça e a mulata Úrsula das Virgens usavam mal de si, tratando-se com quem lhes parecia, servindo aos seus senhores de todo o serviço de porta a fora", especialmente Luzia. ${ }^{36}$ Gaspar da Rocha Maia, 56 anos, foi ainda mais explícito na sua condenação das duas escravas:

[...] disse que Luzia mestiça e Úrsula das Virgens eram de maus procedimentos por tratarem ilicitamente com brancos e pretos, e que não eram pessoas pelas suas qualidades e condições que aos seus ditos se desse crédito em juízo, e fora dele, por serem de pouca verdade e reputação. ${ }^{37}$

É recorrente nas fontes um padrão moral que estigmatizava as mulheres que não se encontravam sob a norma da domesticidade. No mundo basicamente rural do interior da Bahia setecentista, o antagonis-

36 ANTT, IL, Caderno do Promotor n. ${ }^{\circ}$ 94, fls. 19-20.

37 ANTT, IL, Caderno do Promotor n. ${ }^{\circ}$ 94, fl. 20. 
mo entre a casa e a rua também se manifestava, ainda que sob outra roupagem. Não é outro o sentido da designação "mulheres de fonte e rio". Era o estigma das mulheres que realizavam "serviços de portas a fora", talvez mesmo tarefas do cotidiano, como a lavagem de roupas e o pegar água nas fontes, riachos e rios. Percebe-se, portanto, que as expressões "servir ao seu senhor de fonte e rio" ou "de todo o serviço de porta a fora" estavam carregadas de significados, e significados negativos. As mulheres a que se referiam "quebravam a regra que ligava recato e domesticidade". ${ }^{38} \mathrm{~A}$ associação ao exercício do meretrício, por sua condição de cativas e sua ocupação cotidiana, muitas vezes exercida fora do ambiente doméstico, era automática na percepção de seus vizinhos da freguesia de Maraú. Acrescente-se a isso o exercício do controle sobre a própria sexualidade de uma maneira que fugia às normas da comunidade, da moralidade setecentista. Daí elas viravam "mulheres de baixa sorte" que "faziam mal uso de si" e eram classificadas, segundo essa lógica, como "mulheres públicas", "mulheres do trato e do mundo", "que tratam ilicitamente com brancos e pretos".

A atmosfera de misoginia racista que influenciava as relações na Colônia atingia também as mulheres envolvidas nas denúncias de solicitação. Apesar do cuidado de um ou outro dos homens que atestaram sobre o crédito e o comportamento das duas escravas em não levantar falso testemunho, afirmando que não sabiam que fossem mentirosas, percebe-se, nos seus discursos, a desaprovação velada de sua conduta, que se desviava dos padrões morais idealizados. A opinião dos homens chamados a falar sobre Luzia Filgueira e Úrsula das Virgens pendeu para a desconfiança cautelosa, quando não para o descrédito velado.

Mas não foi somente a imagem das escravas que saiu maculada nas inquirições do Santo Ofício. Também foram ouvidas cinco testemunhas sobre o crédito e o comportamento de frei Leandro Soares. O negociante Pascoal de Oliveira, 50 anos, natural do Porto e morador no Curral Velho, na Cidade da Bahia, disse que o conhecia havia muitos anos, desde a sua entrada na religião, e ele "sempre vivera com bom procedimento, vida e costumes, e com opinião de religioso". Acrescen-

38 Lara, Fragmentos setecentistas, pp. 120-1. 
tou, no entanto, que o frade vivera fora de seu convento, sem licença de seus prelados, estabelecendo-se por alguns anos na vila de Camamu. Essa retirada do convento, segundo ele ouvira dizer, havia ocorrido porque o carmelita estava em conflito com novos prelados. Outro negociante português, José de Azevedo, 60 anos, natural de Lisboa e morador na Bahia, na Praia, também referendou o bom procedimento do frade e disse "que só era notado da pouca residência que fazia no seu convento, por ser de gênio dado a viver fora dele". A essa explicação um tanto vaga, acrescentou "que não sabia, nem ouvira dizer que o não assistir no dito seu convento fosse por causa, ou motivo escandaloso, porque não lhe soubera nunca de vícios ou maus costumes que tivesse". José de Azevedo atribuía a prisão do religioso a essas escapadelas do convento. ${ }^{39}$

As referências positivas sobre frei Leandro Soares ficaram somente nestes dois depoentes. Atanásio Barbosa de Faria, 40 anos, morador em Água de Meninos, acusou-o de ser dado ao vício do jogo, mencionando que o viu algumas vezes, na casa do pai, "jogando ao truque do taco publicamente". Acrescentou que o frade andou apóstata alguns anos, vivendo na vila de Camamu, onde saía à noite com armas, em traje de secular, e, por seu "gênio revoltoso", inquietava com demandas o povo daquela vila. Também "era dado ao vício da lascívia, de que era notado", sentenciou. ${ }^{40} \mathrm{O}$ padre Francisco Xavier Prazeres, 36 anos, sacerdote de São Pedro, beneficiado na Sé da Bahia, foi ainda mais severo:

[...] disse que o dito padre frei Leandro era de mau procedimento, vida e costumes, escandalizando aos seculares com o seu mau exemplo, e que algumas vezes o vira ele testemunha em traje de secular, e que era muito dado aos vícios da sensualidade, e jogo, de que era notado, e que o que tem dito sabia pelo ver e ouvir dizer geralmente. ${ }^{41}$

O religioso de São Pedro ainda acrescentou que ouvira dizer que frei Leandro tinha sido preso pelo visitador-geral das vilas do sul, o

\footnotetext{
9 ANTT, IL, Caderno do Promotor n. ${ }^{\circ}$ 94, fl. 34

40 ANTT, IL, Caderno do Promotor n. ${ }^{\circ}$ 94, fl. 35

41 ANTT, IL, Caderno do Promotor n. ${ }^{\text {9 } 94, ~ f l . ~} 35$.
} 
doutor Pascoal Fernandes Monteiro, na vila de Camamu, e de lá remetido ao seu convento na Cidade da Bahia. O motivo da prisão foi "por culpas de solicitação no confessionário". A última testemunha ouvida, o oficial de ourives Francisco Dias da Rocha, 46 anos, natural e morador na capital, não acrescentou muita informação, sendo bastante econômico em sua fala. Disse simplesmente que "o dito padre frei Leandro não era de bom procedimento, por ser dado a vícios, sendo mais notado de incontinente e jogador". ${ }^{42} \mathrm{O}$ inquérito se encerra sem informar qual foi o destino do frei Leandro Soares. Mas tudo indica que ele não chegou a ser preso e processado pelo Santo Ofício. É possível que a punição de seus desvios, se punição houve, tenha se dado pelos próprios superiores de sua ordem religiosa, com atribuição de penitências espirituais.

\section{"Públicas para quantos as queiram"}

A mesma expressão "mulheres de fonte e rio" já havia sido utilizada vários anos antes, no início do século XVIII, em outra diligência sobre crime de solicitação ocorrido no Recôncavo da capitania da Bahia. Era o ano de 1705, e o acusado, Luís de Souza Marques, vigário da matriz de São Gonçalo, da vila de São Francisco de Sergipe do Conde. O vigário era "useiro e vezeiro a levar as mulheres que confessa para a sacristia depois de lhes dar a comunhão", conforme denúncia assinada por diversos moradores, todos do sexo masculino, figuras proeminentes da sociedade local. Mudava-se o cenário da conquista amorosa do confessionário para a sacristia. As mulheres apresentadas como vítimas da solicitação, no entanto, correspondiam à mesma condição social das escolhidas de Maraú pelo frei Leandro Soares, resvalando nos limites entre a escravidão e a liberdade. Eram elas: Custódia, mulher parda e forra; Maria Carvalho, mestiça forra; Micaela dos Anjos, moça parda e forra; Antônia, parda, escrava; Leonor, preta, escrava. ${ }^{43}$

Essa queixa sobre o mau procedimento do vigário foi entregue ao

\footnotetext{
${ }^{42}$ ANTT, IL, Caderno do Promotor n. ${ }^{\circ}$ 94, fl. 35.

${ }_{43}$ ANTT, IL, Caderno de Solicitantes n. ${ }^{\circ}$ 17, fls. 238-9, <http://digitarq.dgarq.gov.pt/ details?id=2390531>, acessado em 21 jul. 2012.
} 
próprio arcebispo da Bahia, D. Sebastião Monteiro da Vide, durante uma visita que a autoridade fez àquela freguesia. De posse da queixa e petição assinada pelos paroquianos, o arcebispo "mandou por seus despachos que o licenciado Manuel Teles, vigário da vara do distrito de Sergipe do Conde, inquirisse as testemunhas" ${ }^{44}$ Nessa diligência feita pelo vigário da vara, foram ouvidas 23 testemunhas. Mas o caso não ficou por aí. $\mathrm{O}$ próprio "Ilustríssimo Senhor Arcebispo, estando visitando na freguesia de São Gonçalo da Vila de São Francisco, aí inquiriu algumas testemunhas com o cônego Gaspar Marques Vieira, secretário da visita". ${ }^{45}$ Tratou-se, portanto, de uma diligência levada a cabo ou acompanhada de perto pela própria autoridade maior da Igreja na América Portuguesa.

Findas as diligências da Justiça eclesiástica, em $1^{\circ}$ de dezembro de 1705, D. Sebastião solicitou ao cônego Gaspar Marques Vieira, comissário do Santo Ofício, que dirigisse o traslado dos autos que estavam em poder "do escrivão do Auditório Eclesiástico Tristão da Cunha Aguiar", para se remeter o caso ao Tribunal da Santa Inquisição, nomeando no mesmo ato como escrivão do traslado o seu próprio secretário, o padre Manoel Ferreira de Matos. ${ }^{46}$

No tocante ao crime de solicitação, esse caso apresenta complicadores a mais do que o de Maraú. A quantidade de testemunhos colhidos durante as diligências já é um indicador das ambiguidades, incongruências e falas desencontradas que marcaram a exposição dos fatos. Apenas para resumir um aspecto do ocorrido, que não será explorado a fundo neste trabalho, basta dizer que, na fala de diversos depoentes, inclusive de mulheres arroladas como vítimas do assédio, surgiu uma denúncia contundente de que o padre Luís de Souza Marques era, na verdade, vítima de uma grande trama de seus inimigos, que haviam forjado os supostos crimes de confessionário, até mesmo pagando ou tentando pagar a uma das mulheres citadas para sustentar a acusação perante as autoridades eclesiásticas e inquisitoriais.

O caminho escolhido para salientar a injúria que se levantava contra o vigário da freguesia de São Gonçalo, no entanto, foi o mesmo da

${ }^{44}$ ANTT, IL, Caderno de Solicitantes n. ${ }^{\circ}$ 17, fl. 238.
45
ANTT, IL, Caderno de Solicitantes n.

${ }^{46}$ ANTT, IL, Caderno de Solicitantes n. ${ }^{\circ} 17$, fl. 237. 
desqualificação feminina. Isso fica evidente no depoimento de Antônio Luís, 50 anos, senhor de um barco que navegava nos arredores da vila de São Francisco. Ele argumentou que muitos dos que atestavam sobre a má conduta do vigário eram, no presente, seus desafetos, mas já haviam sido amigos, a ponto de comerem e beberem todos em sua companhia. Esses mesmos antigos amigos diziam que o vigário solicitava mulheres na confissão, ao que ele nunca deu crédito, por ouvi-los "nomear negras e mulatas e todas mulheres públicas de todos quantos as querem". O pescador Luís Pereira, 38 anos, também foi bastante contundente na descrença sobre o assédio e, sobretudo, em estigmatizar as mulheres: "perguntado no duodécimo artigo jura ele testemunha que esta é a primeira vez que ouve tudo quanto nele se contém, porquanto as tais mulheres foram sempre de fonte, e rio, e públicas para quantos as queiram". Outra testemunha, Pedro Dutra de Andrade, 63 anos, lavrador de canas, ao ser perguntado sobre o mesmo artigo que continha a acusação contra o vigário, disse secamente "que dele não sabia coisa alguma, e que as tais mulheres nomeadas neste artigo são indignas de serem solicitadas em semelhante auto, por serem mulheres de fonte e rio". ${ }^{47}$

Entre as cinco mulheres apontadas na denúncia como vítimas do assédio, três compareceram e negaram o fato. Antônia, parda, escrava de João de Matos, além de negar a ocorrência da solicitação, fez questão de enfatizar que "o vigário Luís de Souza Marques a confessara muitas vezes e que sempre a repreendera de seus pecados". ${ }^{48}$ Maria Carvalho, mestiça forra, casada com o crioulo Antônio de Araújo Sandes, mas "que em algum tempo foi mulher solteira e do trato", segundo anotou o escrivão, também negou o assédio do vigário e ainda forneceu detalhes da trama que procurava enredá-lo no crime de solicitação:

Jura ela testemunha que há nove anos que o reverendo vigário Luís de Souza Marques é seu compadre, sendo ela ainda solteira, e que é falso dizer-se que ele solicitara a ela na confissão, porquanto se confessara com ele muitas vezes e nunca tal sucedera. E que há três para quatros anos que Cosme Rolim de Moura persuadira a Luís Costa de Oliveira

\footnotetext{
${ }^{47}$ ANTT, IL, Caderno de Solicitantes n. ${ }^{\circ}$ 17, fl. 242 (grifos meus)
}

48 ANTT, IL, Caderno de Solicitantes n. ${ }^{\circ} 17$, fl. 239. 
fizesse com que ela quisesse dizer e jurar que o reverendo vigário a solicitara na confissão, e que também o juiz dos órfãos da dita vila pedira o mesmo ao dito Luís Costa de Oliveira. ${ }^{49}$

Outras testemunhas também denunciaram a trama. Entre elas, o padre João Vieira Leite, 60 anos, que, mesmo sendo inimigo declarado do padre, confirmou que, em uma visita que o cônego João Calmon, comissário do Santo Ofício, fizera à vila de São Francisco, Cosme Rolim de Moura e Luís de Valensuela Ortiz, juiz de órfãos, ofereceram oito mil réis a Maria Carvalho para que ela fizesse a denúncia. ${ }^{50}$

Em outro depoimento, prestado ao próprio arcebispo da Bahia, Maria Carvalho voltou a insistir na inocência do vigário, esclarecendo que, três anos antes, quando era ainda solteira, ela mantinha um "trato" com um homem da vila que era muito amigo do referido Luís Costa de Oliveira, meirinho de campo, e que esse homem, a pedido do meirinho, agenciou para que ela acusasse o vigário. Ela não somente repetiu que nunca aceitou fazer tal acusação injuriosa, como fez questão de dizer que não houve nenhum envolvimento sexual seu com o vigário. O homem da vila com quem se relacionava

[...] lhe induzira várias vezes, rogando-a que quisesse dizer que o vigário Luís de Souza Marques a cometera e solicitara na confissão, o que ela não quisera fazer, antes estranhou muito, e que nem com ele tivera nunca nada, sendo ela então mulher pública do mundo. ${ }^{51}$

Mesmo considerando a mediação do escrivão, chama atenção o fato de que, em sua própria fala, ela se autoidentifica como "mulher pública do mundo", talvez fruto da consciência que tinha de que, por sua conduta, pesava sobre ela certa margem de desonra social. Essa margem de desonra, não raro, sujeitava mulheres como Maria Carvalho a sofrer as contingências da vida cotidiana, entre elas o assédio sexual, inclusive da parte de padres. Entretanto, ela insistia na defesa do vigário, que teria lhe repreendido diversas vezes em confissão por conta de seus pecados, provavelmente relacionados com a carne.

\footnotetext{
9 ANTT, IL, Caderno de Solicitantes n. ${ }^{\circ}$ 17, fl. 239.

50 ANTT, IL, Caderno de Solicitantes n. ${ }^{\circ}$ 17, fl. 239.

${ }^{51}$ ANTT, IL, Caderno de Solicitantes n. ${ }^{\text {o }}$ 17, fl. 244 (grifo meu).
} 
Também Custódia Pereira, parda forra, que aparece na lista das mulheres assediadas pelo padre, negou que o fato tivesse acontecido. Ela jurou que, quando foi moradora na vila, havia se confessado com ele, e que nunca a solicitara na confissão. No entanto, em uma informação ligeira, quando se mencionou "o costume", deu conta de pecados da juventude do vigário: "ao costume disse que sabia que o reverendo padre vigário Luís de Souza Marques, sendo estudante, havia tido cópula com a mãe dela testemunha". ${ }^{52}$ Não se deve, entretanto, supervalorizar essa informação, e os inquisidores certamente não o fizeram na época. Eram pecados de naturezas diferentes, a solicitação sendo um crime punido pelo Santo Ofício, enquanto o trato ilícito ou fornicação, uma falta menos grave, sujeita ao controle dos poderes eclesiásticos, dos bispos locais.

A única das mulheres arroladas a confirmar que o padre Luís de Souza Marques a havia solicitado na confissão foi Micaela dos Anjos, 18 anos, parda forra, solteira. A tentativa de sedução teria se dado em pelo menos três ocasiões, ocorrendo a primeira havia cinco anos, no ano de 1700, portanto, quando Micaela ainda era "moça donzela". Na segunda investida, ocorrida dois anos depois, o vigário se aproveitou espertamente do segredo de confissão, de um pecado relacionado ao sexto mandamento:

[...] que ao depois, em outra ocasião, se fora confessar com ele e que conhecendo pela confissão que já não era honesta a tornou a cometer segunda vez, dizendo-lhe que já então não tinha que recear por haver perdido a sua honestidade, que se tirasse da casa onde estava e viesse morar na vila que ele the poria casa e the daria negras para a servir. ${ }^{53}$

Por um lado, esse testemunho sugere como para os confessores era difícil a tarefa de esquadrinhar desejos e atos sexuais dos fiéis sem se deixar contagiar pelo imaginário de sensualidade que envolvia as confissões dos pecados da carne. Lana Lima verificou que o momento em que era abordado o sexto mandamento durante a confissão, tornavase a ocasião mais propícia para as propostas amorosas dirigidas pelos

${ }^{52}$ ANTT, IL, Caderno de Solicitantes n. ${ }^{\circ}$ 17, fl. 244.

53 ANTT, IL, Caderno de Solicitantes n. ${ }^{\circ} 17$, fl. 240. 
confessores às penitentes. ${ }^{54}$ Por outro lado, a atitude de diversos clérigos que lançavam mão do próprio teor da confissão para colocar em ação suas conquistas amorosas desvelam o território de poder e abuso que atravessava o cotidiano de muitas mulheres em sua vivência religiosa no período colonial. No caso de Micaela dos Anjos, o padre tornou-se ainda mais insistente no seu assédio quando tomou conhecimento de que a moça cobiçada havia pecado contra a castidade, deixando de ser virgem. É possível perceber a associação entre virgindade e honestidade. Micaela dos Anjos deixou de ser honesta quando deixou de ser virgem sem estar coberta pelo manto sagrado do matrimônio. Como argumenta Lana Lima, por trás do comportamento desviante de alguns confessores, estavam ecos de velhas opiniões que consideravam o exercício da sexualidade como direito dos homens e dividia as mulheres entre puras e públicas. ${ }^{55}$

Micaela dos Anjos era moradora na Ilha da Cajaíba. Tudo indica que se tratava de uma moça pobre, talvez alforriada ainda criança. Sabese que, na época da devassa, estava recolhida na casa de Francisco Ferreira da Câmara e que antes vivera na companhia dos pais deste, também na Cajaíba. Em outro depoimento feito perante o arcebispo D. Sebastião Monteiro da Vide e o comissário Gaspar Marques Vieira, secretário da visita, ela contou que o primeiro assédio do vigário foi acompanhado de inúmeras promessas. Se ela "quisesse ser sua amiga, e ir para a sua casa, que lhe daria todo o necessário: cordões, argolas, vestidos, e lhe não faltaria nada". Enquanto fazia essas promessas, tocava-lhe os seios. Tendo ela se levantado sem prosseguir na confissão, o vigário fingiu que a absolvia, "tratando-a por vós e com palavras afetuosas", ${ }^{56}$ por perceber que eram observados por pessoas presentes na igreja.

Margarida Ferreira, irmã de Francisco Ferreira da Câmara, última testemunha a depor nos autos, foi ouvida pelo vigário da vara do distrito, Manuel Teles, que se dirigiu à Ilha da Cajaíba por ordem do arcebispo da Bahia. Ela disse ao visitador que Micaela dos Anjos foi à igreja, na ocasião, em companhia dela e de sua mãe, Isabel Rodrigues,

\footnotetext{
${ }^{54}$ Lima, “A confissão pelo avesso", pp. 564-5.

${ }^{55}$ Lima, "A confissão pelo avesso", p. 614.

56 ANTT, IL, Caderno de Solicitantes n. ${ }^{\circ}$ 17, fl. 245. 
já falecida na época da visita. Margarida acrescentou que sua mãe percebeu quando o vigário conduziu Micaela para a sacristia. De onde estava na igreja, Isabel observava a sacristia e estranhou a situação:

E que ao depois de virem da igreja perguntara sua mãe a Micaela dos Anjos o que tivera com ele vigário, quando a estava confessando e que ações eram aquelas que lhe fazia com as mãos até chegar a pô-las nos peitos? Ao que a moça, mostrando-se envergonhada, não respondera. ${ }^{57}$

Isabel Rodrigues teria então insistido com a filha Margarida que "tirasse de Micaela que ações eram aquelas que o vigário tivera com ela na confissão". Assim feito, Micaela confessou a Margarida "que o vigário Luís de Souza Marques a solicitara na confissão, dizendo-lhe fosse viver na vila, aonde ele lhe poria casa e a sustentaria, porquanto a queria para sua concubina". Margarida Ferreira também acrescentou que houve outras tentativas de sedução, fato que levou Micaela a deixar de confessar-se na igreja matriz de São Gonçalo, da vila de São Francisco: "e que fugindo pelas Quaresmas de se confessar com ele se confessava fora da matriz" ${ }^{58}$ Conforme ela própria, o vigário somente deixou de assediá-la em confissão quando ela ameaçou que mudaria definitivamente de freguesia para não ser mais obrigada a confessar-se com ele. ${ }^{59}$

A Ilha da Cajaíba, onde morava Micaela dos Anjos, era ocupada por uma comunidade pequena, provavelmente sem muitos horizontes para uma moça pobre como ela que vivia acolhida por uma família que não era a sua, e talvez fosse mesmo de antigos senhores. No tempo da sua mocidade, ainda não existia na localidade o grande engenho Cajaíba, cujo casario mais suntuoso foi erguido no século XIX. Cerca de meio século após o que aqui foi relatado, em 1757, a ilha (que tinha um quarto de légua de extensão) estava "quase despovoada", contando somente "com cinco moradores" ${ }^{60}$ Nesse cenário, é bastante provável que pro-

\footnotetext{
57 ANTT, IL, Caderno de Solicitantes n. ${ }^{\circ}$ 17, fl. 246

58 ANTT, IL, Caderno de Solicitantes n. ${ }^{\circ} 17$, fl. 246.

59 ANTT, IL, Caderno de Solicitantes n. ${ }^{\circ}$ 17, fl. 240.

${ }^{60}$ "Noticia sobre a Freguezia de S. Gonçalo da Villa de S. Francisco da Barra de Sergipe do Conde, pelo Vigario collado Valentim dos Santos Neves". Annaes da Bibliotheca Nacional do Rio de Janeiro, v. 31 (1913), pp. 206-7, <http://objdigital.bn.br/acervo_digital/anais/ anais_031_1909.pdf>, acessado em 19 fev. 2013.
} 
messas como as do vigário Luís de Souza Marques, de levar Micaela para a vila de São Francisco, "aonde lhe poria casa", e sustentá-la como concubina, representasse alguma tentação.

Mas não se sabe se o que contou Micaela dos Anjos era verdade ou se fazia parte do suposto repertório de intrigas para incriminar o vigário da matriz de São Gonçalo. No entanto, não deixa de ser bastante verossímil. Padres enamorados por suas paroquianas houve muitos, assim como muitas eram as moças que se encantavam pelos homens de batina. É possível supor que o padre tivesse fama de comportamento pouco exemplar no confessionário e que essa fama tenha sido utilizada por seus desafetos para ampliar o rol de seus pecados, fosse desencavando solicitações verdadeiras ou mesmo inventando fatos. A experiência narrada na denúncia de Micaela dos Anjos guarda semelhança com outras tantas vividas por mulheres no Brasil escravista. Apesar de "serem os sacerdotes de Deus, os oficiantes do culto, os intermediários que ligavam os homens ao campo religioso", como argumenta Laura de Mello e Souza, a historiografia está cheia de exemplos de padres intrépidos, que se resvalavam nos delitos da carne, em aventuras passageiras ou sustentando um concubinato, vivendo com suas companheiras "de portas adentro", como teria sido a proposta do vigário Luís de Souza Marques para Micaela dos Anjos. ${ }^{61}$

\section{"Por ser neta de mulata, as quais costumam mentir"}

A experiência da sexualidade colonial, apesar do empenho de Gilberto Freyre em adocicá-la, como refere Ronaldo Vainfas, foi temperada pela misoginia e pelo estigma racial. Não faltou nesse processo a humilhação das mulheres, combinada à exploração da miséria com preconceitos diversos. ${ }^{62}$ Verena Stolcke, por seu turno, demonstra que o sistema de identificação e classificação social baseado no ideal de pureza de sangue, presente na sociedade ibérica, marcou também as relações de gênero e a experiência das mulheres na sociedade colonial. Sob a influên-

${ }^{61}$ Laura de Mello e Souza, Inferno atlântico: demonologia e colonização, séculos XVI-XVIII, São Paulo: Companhia das Letras, 1993, p. 143

62 Vainfas, "Moralidades brasílicas", pp. 241-2. 
cia da cultura ibérica em que a posição social tinha por base a genealogia, a descendência, o controle da sexualidade feminina tornava-se decisivo. Somente as mulheres podiam certificar sobre a legitimidade dos nascimentos. A Igreja reforçou essa mentalidade de controle enaltecendo a virtude sexual das mulheres - virgindade antes do casamento e fidelidade depois - como o maior de todos os bens morais. ${ }^{63}$

Controlar o corpo da mulher, a sua sexualidade, significava também o controle da reprodução adequada da sociedade, pelas lógicas genealógicas do sangue e, depois, da raça. Verena Stolcke insiste, no entanto, em que somente pouco a pouco, na sociedade colonial, os princípios de classificação social que tinham por base o nascimento, a genealogia, adquiriram um sentido racial. Durante os dois primeiros séculos depois da conquista, a limpeza de sangue se referiu mais a qualidades cultural-religiosas do que a qualidades raciais. ${ }^{64}$ Mas é possível surpreender, ao longo do processo de colonização, como o fenótipo foi se tornando um indicador importante de qualificação social. Nas questões de política local, por exemplo, no espaço atlântico português, a questão da cor estava bem presente e "ser branco se transformava numa primeira forma de distinção", conforme argumento de João de Figueirôa-Rêgo e Fernanda Olival. ${ }^{65}$ Ainda que o racismo moderno só tenha aparecido no século XVIII e se desenvolvido como teoria científica no XIX, é possível supor que a sua sedimentação se deu ao cabo de um longo processo, com raízes certamente bem antigas. Giuseppe Marcocci sinaliza a hipótese de que os estatutos de limpeza de sangue, que se desenvolveram sob um paradigma antijudaico, principalmente, mas que se estendeu a outros grupos, entre eles ameríndios, negros e mulatos, re-

\footnotetext{
63 Stolcke argumenta que, na cultura ibérica, a doutrina da pureza ou limpeza de sangue era entendida como a qualidade de não ter como ancestral um mouro, um judeu, um herético ou um condenado pela Inquisição. O sangue era então concebido como um veículo de pureza da fé que transmitia vícios e virtudes religioso-morais de uma geração a outra. Essa doutrina estará presente na hierarquização da sociedade colonial, sobretudo durante os dois primeiros séculos da colonização. Avançando a colonização, a linguagem da limpeza de sangue obtém nova relevância, perdendo sua conotação religioso-moral prévia e adquirindo um sentido racial. Verena Stolcke, "O enigma das interseções: classe, 'raça', sexo, sexualidade. A formação dos impérios transatlânticos do século XVI ao XIX”, Estudos Feministas, v. 14, n.1 (2006), pp. 21-5 e 33-4.

64 Stolcke, "O enigma das interseções", pp. 29-30.

65 Figueirôa-Rêgo e Olival, "Cor da pele, distinções e cargos", p. 119.
} 
presentou uma contribuição original do mundo ibérico, apesar de indireta, para a gênese do racismo moderno. ${ }^{66}$

Em outras denúncias de solicitação no confessionário, o mesmo padrão discriminatório que atingia as mulheres, particularmente negras e mestiças, já aparece plenamente formado. Como no último caso narrado, outros também se passaram no Recôncavo da capitania da Bahia, no centro da região açucareira, ou "berço do massapé", conforme Stuart Schwartz. Um deles ocorreu na freguesia de Passé, ou Nossa Senhora da Encarnação do Passé, situada à beira-mar pelo lado do poente, com uma população estimada em 4.160 pessoas, no ano de 1724, das quais 2.677 eram escravas. ${ }^{67}$

Algumas décadas mais tarde, em 1757, um vigário local lamentava a situação da freguesia, que, segundo ele, havia sido em algum tempo uma das melhores do Recôncavo, mas, naquele momento, se achava enfraquecida "por viverem os lavradores de açúcar, maior e principal tráfego desta terra, quase todos empenhados e arrastados pela carestia dos escravos, e mortandade d'elles" ${ }^{68}$ A freguesia de Passé contava, na época, com 303 fogos ou domicílios, onde viviam 2.370 pessoas, em sua maioria escravos dos lavradores de cana. A redução da população em quase metade, comparada com aquela estimativa de 1724, pode ser explicada por uma divisão que a freguesia sofreu no tempo do rei D. João V (1706-1750), dando origem à de São Sebastião. Segundo Schwartz, "os habitantes de Nossa Senhora do Passé queixaram-se ao perder um distrito contendo cinco engenhos e 2.500 almas devido à criação da nova paróquia de São Sebastião do Passé, em 1729" . ${ }^{9}$

Mas, voltando à solicitação, do crime denunciado em Nossa Se-

${ }^{66}$ Giuseppe Marcocci. "Escravos ameríndios e negros africanos: uma história conectada. Teorias e modelos de discriminação no império português (ca. 1450-1650)". Tempo, v. 16, n. 30 (2011), p. 51, <http://www.scielo.br/pdf/tem/v16n30/a03v16n30.pdf>, acessado em 18 fev. 2013.

${ }^{67}$ Stuart B. Schwartz, Segredos internos: engenhos e escravos na sociedade colonial, São Paulo: Companhia das Letras, 1988, p. 87.

68 "Relação da Freguezia de Nossa Senhora da Encarnação de Passé, e dos sítios e lugares, rios, seus nomes e distância e juntamente das pessoas que n'ella e nas capelas suas filiaes ao presente se compreendem, pelo Vigario Antonio da Costa Pereira". Annaes da Bibliotheca Nacional do Rio de Janeiro, v. 31 (1913), pp. 206-7, <http://objdigital.bn.br/acervo_digital/ anais/anais_031_1909.pdf>, acessado em 19 fev. 2013.

${ }_{69}$ Schwartz, Segredos internos, p. 81. 
nhora do Passé no início do século XVIII era acusado o padre Antônio Fernandes de Souza de haver solicitado, no ato da confissão, a duas mulheres: Margarida das Neves, viúva, moradora no Carijó, e Maria de Melim, parda, escrava de Atanásio de Melim, moradora no local chamado Jangada. A ordem para a diligência foi passada pelo Santo Ofício em dezembro de 1698, mas somente aconteceu em junho de 1700 , e as testemunhas foram ouvidas "no sítio do Carmo na outra banda do rio Jacuípe, na casa que tem os religiosos do Carmo, no seu engenho, que é na freguesia de Passé". ${ }^{70}$ Coube ao padre Lourenço Ribeiro, vigário da freguesia, realizar a diligência conforme as ordens do comissário Inácio de Souza Brandão. Os escrivães foram Manoel Pereira, "religioso carmelita observante", e Manoel das Neves Belmonte, coadjutor na freguesia vizinha, Nossa Senhora da Piedade de Matuim.

Em seu depoimento, a viúva Margarida das Neves não confirmou a informação de que o padre Antônio Fernandes de Souza a tivesse solicitado durante a confissão sacramental ou fora dela e desembaraçou-se do caso rapidamente, dizendo simplesmente "que lhe não lembrava de que confessor algum a solicitasse no ato da confissão, nem ouvira a pessoa alguma queixar-se disso". ${ }^{71}$

A escrava Maria de Melim, no entanto, contou em seu depoimento como o padre Antônio Fernandes de Souza não somente a solicitara em várias confissões, mostrando, portanto, ser um sedutor pertinaz, como tentara forçá-la a manter com ele relações sexuais:

[...] por várias vezes indo ela depoente confessar-se com ele a solicitara para atos torpes e desonestos de palavra e abraçando-a, lutando com ela, antes de ela começar a confissão sacramental, querendo-a forçar por ela não consentir, e por várias vezes se livrou dele dizendo-lhe que havia de gritar e, com efeito, havia de gritar se ele não a largara. ${ }^{72}$

O mesmo procedimento de apurar o crédito e a conduta das mulheres foi usado nessa diligência. Isso se deu mesmo no caso de Marga-

\footnotetext{
${ }^{70}$ ANTT, IL, Caderno de Solicitantes n. ${ }^{\circ}$ 15, fls. 398-403, <http://digitarq.dgarq.gov.pt/ details? $\mathrm{id}=2390506>$, acessado em 10 jun. 2012.

71 ANTT, IL, Caderno de Solicitantes n. ${ }^{\circ}$ 15, fl. 404.

72 ANTT, IL, Caderno de Solicitantes n. ${ }^{\circ} 15$, fl. 403.
} 
rida das Neves, que negou a ocorrência de qualquer crime de solicitação. Os cinco depoentes eram, mais uma vez, homens, moradores na vizinhança das supostas vítimas e delas bem conhecidos. Todos atestaram positivamente quanto ao crédito das mulheres, afirmando que nunca ouviram dizer que fossem mentirosas ou acostumadas a levantar falso testemunho. No que se refere à conduta e à reputação, no entanto, os discursos foram desde a exaltação, em se tratando da viúva Margarida das Neves, salvo uma exceção, a resignadamente negativos, no caso da escrava Maria de Melim, ainda que se perceba um esforço dos homens chamados a depor em realçar qualidades éticas de ambas as mulheres.

João do Lago, 45 anos, morador na Capivara, lugar próximo ao engenho do Carmo, disse que Margarida era mulher de "bom procedimento, reputação e verdade, pobre, mas recolhida e que viveu sempre às asas de seus irmãos". Seu pai, Daniel do Lago, 78 anos, morador na Capivara, também confirmou a boa reputação de Margarida, assim como o vizinho desta, Luís da Silveira, 50 anos, morador no Carijó. João de Melim, 28 anos, morador na fazenda e engenho do Carmo, também reforçou que a viúva era de bom procedimento e vivia na companhia de seus irmãos. Apenas Euzébio Teixeira, 65 anos, morador no local chamado Pojuca, junto ao Carijó, disse "que consta por ouvir dizer que Margarida das Neves não vive com a castidade devida", mas confirmou que era mulher verdadeira em suas palavras. ${ }^{73}$

Com relação à escrava Maria de Melim a fala dos homens mudou de tom quanto ao comportamento, ainda que se perceba um esforço em apresentar dados positivos sobre ela, a despeito de sua conduta sexual socialmente condenável, conforme a moral da época refletida no discurso dos depoentes. O primeiro deles, João do Lago, disse, meio titubeante, que ela era "mulher solteira que busca sua vida", mas acrescentou que "por ser seu vizinho há muitos anos lhe consta que não é mentirosa" e ainda reforçou que sabia disso também "por ser sobrinho de Atanásio de Melim, senhor da dita escrava Maria, e filho de uma irmã do mesmo". O discurso de seu pai, Daniel do Lago, também é ilustrativo da preocupação em atribuir qualidades éticas à escrava. O septuagenário

73 ANTT, IL, Caderno de Solicitantes n. ${ }^{\circ}$ 15, fls. 408-10 (grifo meu). 
Daniel era genro do senhor de Maria e disse categoricamente: "a escrava Maria, suposto que é solteira e que fora do matrimônio tem parido algumas vezes, é mulher sisuda e capaz, fora de contos, ditos e mentiras". ${ }^{74}$

Maria de Melim era natural de Pojuca, conforme a testemunha Euzébio Teixeira, 65 anos, onde ele próprio também nascera e ainda morava. Ele a conhecia, portanto, desde o nascimento e declarou que ela nunca fora casada e que "a escrava Maria é mulher que busca sua vida pecando com quem lhe parece, porém não ouviu dizer que fosse embusteira, mentirosa, ou acostumada a levantar falsos testemunhos". ${ }^{75}$

A última testemunha a depor, João de Melim, filho do senhor de Maria, também deixou testemunho empenhado em realçar qualidades da escrava, a despeito de seus desvios morais. Ele disse perante o comissário: "a escrava Maria, suposto que parda e mulher que busca sua vida, e peca com quem lhe parece, é tida e havida por sisuda, calada, fora de ditos, contos e enredos". O sinhozinho disse conhecê-la "desde menino", sendo ela filha de uma escrava de seu pai, a preta Bernarda "do Gentio da Guiné". O fato de ser classificada nos autos como parda, sendo filha de uma negra africana, sugere que Maria de Melim teria nascido do encontro de sua mãe com um homem branco. ${ }^{76}$

Mesmo falando positivamente sobre aspectos da vida da escrava, o discurso das testemunhas não deixou de embaraçar-se em estigmas comuns à mentalidade do período. Não é outro, por exemplo, o sentido da expressão conciliadora "suposto que parda", usada pelo sinhozinho. Mesmo sendo parda e com o agravante de pecar contra a castidade, Maria de Melim merecia crédito, conforme João de Melim. Mas a atribuição de crédito foi feita como uma exceção, com teor de extraordinário. A mesma exceção está presente nas adjetivações de que Maria era mulher calada, sisuda e capaz. A qualificação positiva de sua personalidade vinha depois da informação de que a escrava era uma mulher que buscava sua vida pecando com qualquer um e, sem ser casada, tinha "parido algumas vezes". Ser sisuda, calada, fora de ditos e enredos não

\footnotetext{
ANTT, IL, Caderno de Solicitantes n.$^{\text {o }} 15$, fls. 408-9.

75 ANTT, IL, Caderno de Solicitantes n. ${ }^{\circ}$ 15, fl. 409.

76 ANTT, IL, Caderno de Solicitantes n. ${ }^{\circ}$ 15, fl. 410 (grifo meu).
} 
era o comportamento esperado de alguém que fazia uso de sua sexualidade à maneira dela. Apesar da ênfase sobre qualidades éticas nos discursos daqueles homens setecentistas, a primeira premissa foi sempre um realce daquilo que havia de negativo no comportamento das mulheres, daquilo que era socialmente condenável, dos seus desvios morais.

Em outro caso de solicitação que ocorreu na freguesia de Nossa Senhora da Purificação de Sergipe do Conde, denunciado ao comissário do Santo Ofício em 1705, aparecem mais claramente os indícios de desconfiança e discriminação relacionados com uma concepção já claramente racializada. Dessa vez, o envolvido foi o padre Antônio Cordeiro, da capela de Nossa Senhora das Brotas, acusado de assediar, no ato da confissão sacramental, Inês Gomes, "mulher parda em segundo grau por parte de sua mãe", casada com Pascoal Francisco, moradora no sítio chamado Murucu. A denúncia dessa paroquiana foi feita ao comissário Inácio de Souza Brandão, em 1705, pelo padre Francisco Ribeiro da Fonseca, da capela de Nossa Senhora da Lapa, também na freguesia de Nossa Senhora da Purificação. No entanto, ela foi ouvida somente sete anos depois, em 1712, em diligência do Santo Ofício, quando também foram feitas inquirições de testemunhas sobre seu crédito e sua reputação. ${ }^{77}$

A freguesia onde morava Inês Gomes estava ligada à economia açucareira e, segundo consta, a primeira igreja matriz fora construída "no sítio do Engenho do Conde de Linhares fundado na margem do rio Sergipe". Daí o nome que deu origem à freguesia: Nossa Senhora da Purificação de Sergipe do Conde. Tempos depois, em 1704, pelo fato de o sítio em que estava a matriz não ser considerado conveniente, foi fundada uma nova matriz em um sítio localizado "meia légua rio acima", onde já existia uma capela sob a invocação de Santo Amaro. Mais tarde, a freguesia passou a chamar-se Nossa Senhora da Purificação de Santo Amaro. O mesmo nome, Santo Amaro, foi dado à vila que se erigiu em $1727 .^{78}$

\footnotetext{
77 ANTT, IL, Caderno de Solicitantes n. ${ }^{\circ}$ 19, fl. 495, <http://digitarq.dgarq.gov.pt/ details?id=2390637>, acessado em 21 jul. 2012.

78 "Relação da Freguezia de Nossa Senhora da Purificação de Santo Amaro do Reconcavo da Bahia, pelo Vigario José Nogueira da Silva", Annaes da Bibliotheca Nacional do Rio de Janeiro, v. 31 (1913), p. 201, <http://objdigital.bn.br/acervo_digital/anais/ anais_031_1909.pdf>, acessado em 19 fev. 2013; Schwartz, Segredos internos, p. 81.
} 
Segundo Schwartz, o engenho Sergipe, do conde de Linhares, que pertenceu antes ao governador-geral Mem de Sá, ficava pouco além do rio Sergipe e controlava todas as terras que o separavam do mar. Toda a área era conhecida como as "terras de Sergipe do Conde", e nela se formaram várias freguesias que eram o coração da zona açucareira. ${ }^{79}$

No tempo de Inês Gomes e sua peleja com o padre Cordeiro, a freguesia ainda aparece nos documentos como Nossa Senhora da Purificação de Sergipe do Conde. Mas o depoimento se deu "no sítio de Santo Amaro", em 12 de maio de 1712, em "pousadas do licenciado Miguel Teles", o vigário da vara, escolhido para conduzir a diligência. Alguns anos antes, o mesmo Miguel Teles conduzira diligências naquele caso do vigário Luís de Souza Marques, da matriz de São Gonçalo (da vila de São Francisco de Sergipe do Conde), cuja acusação de solicitação foi imputada como conspiração de seus inimigos. Conforme a denúncia de Inês Gomes, o crime de solicitação teria ocorrido no tempo em que ela era ainda "solteira e donzela" e "estava em poder de seus pais". Segundo ela, no momento da confissão, o sacerdote "lhe mostrara grande afeição" e "apertando-lhe as mãos com as suas se pôs a folgar com elas, significando-lhe que queria ter com ela cópula" e que "havia de ir à casa de seus pais para falar mais devagar na matéria". ${ }^{80}$ Tendo prestado seu depoimento perante os condutores da diligência do Santo Ofício, dois padres ratificadores, sacerdotes do hábito de São Pedro e moradores na mesma freguesia de Nossa Senhora da Purificação, assim interpretaram sua narrativa:

E ida para fora a dita testemunha, foram perguntados aos ditos reverendos padres Clemente da Cunha Correia e Inácio Cardoso Machado se lhes parecia que ela falava verdade e merecia crédito, pelo que nela entenderam e disseram que lhes parecia muito diminuta em palavras, e quase por entre os dentes ratificara o seu juramento, e que thes parecia se lhe não devia dar inteiro crédito pela qualidade da mulher por ser neta de mulata, as quais costumam mentir, e ainda que casada e honesta, não ser de qualidade, pelo que não a julgaram por mulher de inteiro crédito. ${ }^{81}$

\footnotetext{
Schwartz, Segredos internos, p. 82.

ANTT, IL, Caderno de Solicitantes n. ${ }^{\circ}$ 19, fl. 495.

${ }^{81}$ ANTT, IL, Caderno de Solicitantes n. ${ }^{\circ}$ 19, fl. 496 (grifo meu).
} 
Aqui percebe-se a naturalização de um suposto defeito, e um defeito que vinha da origem: "mulher parda em segundo grau por parte de sua mãe". O estigma da mulatice poderia servir de elemento de caracterização depreciativa, como demonstra o estudo de Figueirôa-Rêgo e Olival. ${ }^{82}$ Mesmo figurando como casada e honesta, Inês Gomes, na visão daqueles sacerdotes, não tinha alcançado o padrão de qualidade das regras da diferença presentes na sociedade do Antigo Regime. Ela não merecia crédito por ser neta de mulata, e as mulatas costumavam mentir, afirmaram os padres. Era um defeito de cor.

A informação de que Inês Gomes era uma mulher casada e honesta foi dada também pelas cinco testemunhas arroladas para depor sobre seu crédito. Elas disseram ainda que a tinham como pessoa verdadeira em suas palavras, ao contrário do que acharam os padres ratificadores. Os homens nada disseram que pudesse desaboná-la perante o Santo Ofício. A inquirição das testemunhas sobre o crédito, procedimento e reputação de Inês Gomes foi feita na Cidade da Bahia, em maio de 1712, na casa do comissário João Calmon. O motivo: "por se acharem as sobreditas testemunhas acudindo a seus particulares como sempre o fazem neste tempo na carga da Frota" ${ }^{83}$

Uma dessas testemunhas foi o sargento-mor Sebastião Ferreira Pinto, 45 anos, natural do arcebispado de Braga e "morador no Tapemirim, no seu engenho do Amor de Deus", na freguesia da Purificação de Sergipe do Conde. Sebastião disse que conhecia bem Inês Gomes, "filha de Bartolomeu Pinto e de uma parda sua mulher, a qual foi da obrigação da casa" do sogro dele, o alferes José Machado de Miranda, e que havia de seis a oito anos que era casada com Pascoal Francisco. Também disse que a tinha "por bem procedida e com boa reputação" e não sabia que fosse acostumada a mentir ou a levantar falsos testemunhos. Também português, natural de Viana, Baltazar Gomes Ribeiro, 40 anos, morador em Iaçumirim, "fazenda do coronel Pedro Barbosa Leal", foi positivo na sua fala sobre o comportamento de Inês. Disse que não sabia "coisa alguma contra o procedimento e reputação da dita

82 Figueirôa-Rêgo e Olival, "Cor da pele, distinções e cargos", p. 121.

83 ANTT, IL, Caderno de Solicitantes n. ${ }^{\circ} 19$, fl. 502. 
Inês Gomes", nem que fosse "mentirosa ou acostumada a dizer mentiras ou levantar falsos testemunhos", antes a tinha "por uma coitada e bem procedida". Outro português, Manoel Mendes de Oliveira, 47 anos, "morador em São Pedro, na fazenda do coronel Domingos Borges de Barros", também ressaltou suas qualidades éticas, dizendo que tinha "a dita Inês Gomes por mulher verdadeira de bom procedimento e reputação". ${ }^{84}$

A questão da honra, de ser uma mulher casada que vivia honradamente em companhia de seu marido, também foi uma qualidade utilizada pelas testemunhas para destacar a conduta de Inês Gomes. Francisco da Silva Monteiro, 42 anos, natural do bispado do Porto, e morador no Murucu, seu vizinho, portanto, afirmou que a conhecia "desde menina", visto que ele por algum tempo exerceu o cargo de professor de latim e por cerca de dois anos esteve em "casa de Bartolomeu Pinto de Azevedo ensinando a ler aos seus filhos". Bartolomeu era o pai legítimo de Inês. O português disse que não sabia coisa alguma contra o seu procedimento e reputação e acrescentou que a tinha "por mulher honrada, honesta e verdadeira". Viver honradamente também foi uma das expressões usadas por Miguel Nunes de Souza. O carapina, natural da Ilha Terceira, disse que não sabia coisa alguma sobre o procedimento de Inês Gomes, mas "antes tem notícia que vive honradamente com seu marido, nem nunca ouviu dizer que fosse embusteira ou mentirosa" ${ }^{85}$

Já com relação ao padre Antônio Cordeiro, a opinião dos depoentes esteve longe de ser lisonjeira. Eles foram praticamente unânimes em relatar a sua conduta inadequada. Um dos graves pecados apontados foi que o vigário viveu escandalosamente em concubinato com uma mulher casada, chamada Ana Freire, cujo marido se encontrava na Índia, e de cujo concubinato tivera pelo menos dois filhos. Na época da diligência sobre o caso de Inês Gomes, o padre Antônio Cordeiro morava em Salvador, segundo se dizia, ainda em companhia de Ana Freire, que àquela altura já estava viúva. ${ }^{86}$

Conforme Ronaldo Vainfas, o concubinato era visto na legisla-

\footnotetext{
${ }^{84}$ ANTT, IL, Caderno de Solicitantes n. ${ }^{\circ} 19$, fls. 500-1.

85 ANTT, IL, Caderno de Solicitantes n. ${ }^{\circ}$ 19, fls. 501-2.

${ }^{86}$ ANTT, IL, Caderno de Solicitantes n. ${ }^{\circ} 19$, fls. 505-8.
} 
ção eclesiástica como simples variante do pecado da fornicação. Se os amancebados fossem solteiros, a situação constituía-se como ofensa ao sexto mandamento. Em caso de adultério (situação inicial de Ana Freire e do padre Antônio Cordeiro), era grave ofensa ao nono mandamento e à fidelidade conjugal. ${ }^{87}$ As Constituições primeiras do Arcebispado da Bahia, feitas, a partir do sínodo reunido em 1707, por iniciativa do arcebispo D. Sebastião Monteiro da Vide - tendo como secretário João Calmon, comissário do Santo Ofício - , conceituavam o concubinato ou amancebamento como "uma ilícita conversação do homem com mulher continuada por tempo considerável". Também determinava que cabia aos prelados agir sobre o costume, investindo contra os casais que assim viviam por meio de admoestações e aplicando penas, incluindo multas, até esses se emendarem, ou seja, até que houvesse a separação. ${ }^{88}$

No entanto, entre aquilo que pregava a legislação eclesiástica e o cotidiano vivido havia uma distância enorme. Para que se tenha ideia dessa distância, vale citar que o próprio cônego João Calmon, que auxiliou D. Sebastião Monteiro da Vide no sínodo que deu origem às Constituições primeiras, foi imputado de ter um comportamento nada ético ou pouco exemplar em matéria sexual durante o período de atuação do arcebispo anterior, D. João Franco de Oliveira (1691-1700). Em um documento da época, João Calmon era acusado de viver "menos honesto, em parede e meia com Ana de Souza", com quem tinha um "trato ilícito" havia três anos. Mantinha outra relação que causava escândalo geral "com Maria da Encarnação, religiosa do Convento de Santa Clara do Desterro". Também era acusado de viver em "trato ilícito" com várias escravas, comprando-as "sempre para o servirem ou the ganharem". Entre essas escravas estava "Brígida, mestiça, que comprou a Maria da Cruz por preço exorbitante para este fim, por ciúmes da qual, fugindo-lhe de casa, querelou com Glauco de Souza" ${ }^{89} \mathrm{Na}$ época de D. João

\footnotetext{
${ }^{87}$ Vainfas, Trópico dos pecados, p. 81.

${ }_{88}$ Sebastião Monteiro da Vide, Constituições primeiras do Arcebispado da Bahia. Estudo introdutório e edição de Bruno Feitler e Evergton Sales Souza. São Paulo: Edusp, 2010, pp. 488-9.

89 "Queixas do povo da Bahia representado por Antônio da Silva Pinto, contra as opressões e mau procedimento do arcebispo e mais clero". Coleção Luísa da Fonseca, cx. 32, n. 4131, apud Luiz Mott, "O Cônego João Calmon, comissário do Santo Ofício na Bahia setecentista", in Bahia: inquisição \& sociedade, Salvador: EDUFBA, 2010, p. 47-8. Sobre o Santo Ofício 
Franco de Oliveira, João Calmon era vigário-geral do arcebispado da Bahia. A despeito daquelas denúncias, sua importância social só faria crescer nos anos seguintes, tendo ele inclusive pleiteado e ocupado, por longos 36 anos, o cargo de comissário do Santo Ofício na Bahia, aparecendo em vários casos aqui citados. ${ }^{90}$

No mesmo ano de 1705, foi encaminhada à mesa da Inquisição em Lisboa outra acusação de uma moradora do Murucu, onde também morava Inês Gomes. Trata-se da denúncia de Clara de Macedo, mulher parda, solteira, segundo a qual o padre Martinho Freire de Palhares incorrera no crime de solicitação durante sua confissão, ocorrida na Quaresma daquele ano de 1705, na capela de São João de Moribeca. A denúncia ao comissário foi feita pelo padre Francisco Ribeiro da Fonseca, o mesmo que apontara o solicitador de Inês Gomes, depois de ter ouvido o relato de Clara em confissão e de tê-la instruído sobre a obrigação de denunciar o vigário faltoso ao Santo Ofício. ${ }^{91}$

As diligências também se realizaram sete anos depois, em 1712, correndo no mesmo período das apurações sobre o caso de Inês Gomes. A demora era explicada pelo fato de que a ordem para se procederem às inquirições partia da sede da Inquisição, em Lisboa, depois que os inquisidores tomavam conhecimento do fato e julgavam-no relevante, a partir das denúncias remetidas pelos comissários. Em 22 de abril de 1712, Clara de Macedo reafirmou os fatos perante o cônego João Calmon na própria residência deste, na Cidade da Bahia, dando conta de que o vigário Martinho Freire de Palhares a tinha solicitado "com palavras indicativas de cópula futura". O vigário a convidara para ir "passar com ele aquela tarde, e jantaria também com ele, de cujo dito entendeu ela testemunha seria para alguma maldade". ${ }^{92}$

As testemunhas sobre o crédito e a reputação de Clara de Macedo foram ouvidas em 13 de maio de 1712 e, também nesse caso, no sítio de

e sua hierarquia de cargos na Bahia, ver: Grayce Mayre Bonfim Souza, "Para remédio das almas: comissários, qualificadores e notários da Inquisição portuguesa na Bahia (1692-1804)" (Tese de Doutorado, Universidade Federal da Bahia, 2009).

90 Mott, "O Cônego João Calmon", p. 50.

91 ANTT, IL, Caderno de Solicitantes n. ${ }^{\circ}$ 19, fl. 267.

92 ANTT, IL, Caderno de Solicitantes n. ${ }^{\circ}$ 19, fl. 272. 
Santo Amaro, freguesia da Purificação de Sergipe do Conde. A seção foi igualmente conduzida por Manoel Teles, o vigário da vara daquela freguesia e vizinhanças. Os depoentes eram cinco homens, quatro deles naturais de Portugal e um da Ilha Terceira, mas todos moradores no Murucu e, portanto, vizinhos de Clara de Macedo. Nas suas narrativas, percebe-se o preciosismo da ação inquisitorial em detalhar e classificar a origem das mulheres envolvidas no crime de solicitação. Fica evidente também a ambivalência da identificação étnico-racial na sociedade setecentista, sobretudo quando envolvia os designativos "pardo" e "mulato".

Antônio Álvares de Souza, oficial de alfaiate, natural do arcebispado de Braga, afirmou que a conhecia bem, que era "mulher de cor parda com casta de índia do Brasil". Paulo Vieira da Penha, que vivia de tabacos, natural do bispado do Porto, enfatizou que a conhecia muito bem e que era "mulher de cor parda, porém não mulata a que comumente se chamam pardos neste Brasil, porquanto a sua descendência, ouvira ele dizer vinha dos índios, por ser filha de um Jorge Gago, índio". Francisco Álvares Pereira, também natural do bispado do Porto e que vivia na Bahia de suas lavouras de tabaco e roças de cana, simplificou dizendo que "conhecia muito bem a Clara de Macedo, mulher índia", filha de "um Jorge Gago, índio, e de uma índia", mas como o pai dela fora casado duas vezes, ele não sabia de qual das mulheres era filha. Domingos da Mota Morganho, oficial de ferreiro, natural da Ilha Terceira, também afirmou ser ela "mulher índia, e dos índios trás a sua descendência", opinião similar à de Gaspar Correia Monteiro, lavrador de tabaco e mandioca, natural do arcebispado de Braga, que afirmou conhecê-la por ser seu vizinho no Murucu, "a qual pela cor bem mostra ser descendente dos índios da terra". ${ }^{93}$

No quesito da conduta moral, os discursos se aproximaram. Nenhuma testemunha assumiu que Clara de Macedo fosse mentirosa ou acostumada a levantar falso testemunho. Mas eles lhe atribuíram uma parcela grande de descrédito motivada por um comportamento condenável. Para seus vizinhos reinóis, era "mulher mundana do trato", "mulher de mau procedimento e nenhuma reputação", "mulher errada e pelo

${ }_{93}$ ANTT, IL, Caderno de Solicitantes n. ${ }^{\text {19 }}$ 19, fls. 277-9. 
mesmo fato sem nenhuma reputação", "mulher do trato que nunca fora casada e que como tal não tem reputação nenhuma". Além da recorrente desvalorização feminina associada ao uso que as mulheres faziam de sua sexualidade, aparece, na fala dos homens, a condenação da manutenção da situação de solteira. Ser solteira na sociedade colonial gerava desconfiança, desconforto, pois fugia do padrão socialmente divulgado, que valorizava o casal e a vida conjugal. ${ }^{94}$

Cinco testemunhas também foram ouvidas sobre o crédito do acusado. Dessas, apenas o capitão Felipe Nunes Ferreira, 54 anos, natural do arcebispado de Lisboa, morador no Subaé e ali lavrador de canas, foi favorável ao padre Martinho Freire de Palhares. Ele afirmou que não sabia "coisa alguma contra o procedimento, vida e costumes do dito padre", nem que ele dava escândalo na freguesia onde morava. $\mathrm{O}$ padre Francisco Ribeiro da Fonseca, 50 anos, natural do arcebispado de Braga, morador na Bahia, disse que não sabia que o padre Martinho dava "escândalo com sua vida" e só ouviu "murmurar e falar entre algumas pessoas que é alguma coisa inclinado e dado a mulheres, e que sobre o seu procedimento não tem mais que dizer". ${ }^{95}$ Essa informação apareceu na fala do ajudante Baltazar Gomes Ribeiro, 40 anos, natural de Viana e morador em Iaçumirim, que também depôs na diligência sobre o caso de Inês Gomes. O ajudante, no entanto, foi mais categórico em seu depoimento, afirmando:

[...] que o padre Martinho Freire de Palhares é inclinado ao vício de mulheres, por cuja causa se contam algumas histórias dele; e que de presente é o dito padre morador no sítio de Santo Amaro, e ouvira dizer a várias pessoas que o dito padre atualmente tem trato ilícito com uma mulher parda ou mestiça, e isto é o que pode dizer de seu procedimento. ${ }^{96}$

O padre André de Figueiredo Mascarenhas, 28 anos, morador na Bahia e natural da freguesia de São José das Itapororocas, declarou que era público e notório que o padre Martinho Palhares andava "concubinado com uma mulher parda". Também ouvira dizer que ele havia sido

\footnotetext{
94 ANTT, IL, Caderno de Solicitantes n. ${ }^{\circ}$ 19, fls. 277-9.

95 ANTT, IL, Caderno de Solicitantes n. ${ }^{\circ}$ 19, fls. 282-3

${ }^{96}$ ANTT, IL, Caderno de Solicitantes n. ${ }^{\circ}$ 19, fl. 284.
} 
acusado no juízo eclesiástico por uma moça que ele tinha "tirado da casa onde estava recolhida em companhia de um seu parente". Além disso, deu notícia de pelo menos um caso de solicitação que envolveu o acusado, havia quatro anos, fornecendo sobre isso nomes de testemunhas. O padre Luís Botelho de Oliveira, 37 anos, natural de Lisboa e morador em Santo Amaro, forneceu outros pormenores. Uma das novidades do seu relato foi que ele ouvira dizer que o padre Martinho "dava dinheiro a dez por cento", ou seja, fazia empréstimos a juros. Sobre a conduta moral, disse que o acusado era "escandaloso por ser muito inclinado a mulheres" e, por conta dessa inclinação, sua fama era notória em Santo Amaro. Também se referiu ao rapto da moça, acrescentando que ela era filha de José Lopes, morador no Subaé, e que até aquele momento o padre a tinha "de sua mão e em casa separada". Falou ainda que, antes dessa moça, o padre "tivera de sua mão" uma mulher casada chamada Josefa, que, na época da diligência, já estava viúva. ${ }^{97}$

Como nos outros casos, os autos deste último foram encaminhados pelo comissário do Santo Ofício na Bahia à mesa da Santa Inquisição em Lisboa. Mas não consta que o padre Martinho Freire de Palhares tenha sido processado pelo Santo Ofício. Na verdade, nenhum dos casos tratados neste estudo gerou um processo inquisitorial. Os processos de padres solicitantes são relativamente parcos, sobretudo se comparados ao universo dos que foram denunciados.

\section{"Viciosa bastantemente no sexo"}

Aquela mesma naturalização da ideia de defeito de cor atribuída a Inês Gomes aparece em outro caso de solicitação que envolveu o padre João Xavier e a escrava Antônia Barbosa, moradores no Acupe, freguesia de Saubara. Era o ano de 1713, quando ela relatou aos comissários do Santo Ofício que não somente fora solicitada em confissão pelo vigário da capela de São Pedro do Acupe, havia sete para oito anos, como, no mesmo dia, após a missa, ele a recolhera em sua casa, vizinha à capela, e ali mantiveram relação sexual..$^{98}$

${ }^{97}$ ANTT, IL, Caderno de Solicitantes n. ${ }^{\circ}$ 19, fls. 583-4.

98 ANTT, IL, Caderno de Solicitantes n. ${ }^{\circ}$ 19, fl. 582. 
Antônia Barbosa nasceu na Cidade da Bahia, em casa de Bárbara Borges, onde sua mãe também era escrava, porém ela havia sido dada em dote a uma filha da senhora, que se casou com Antônio de Brito Lobo, senhor de engenho no Acupe. Para atestar sobre o seu crédito e procedimento, foram ouvidos cinco mercadores da capital, que a conheciam havia muitos anos, sendo alguns deles familiares do Santo Ofício. Na narrativa desses homens, ainda que todos tenham atestado que às palavras dela se poderia dar crédito, ficou explícito o mesmo rol de avaliações negativas, de cariz sexual aliado ao preconceito de cor, que até aqui vem se procurando demonstrar. "Antônia Barbosa é mulher preta mundana, como são as mais das negras desta terra", sentenciou Pedro Martins Valverde. "Antônia Barbosa é mulher preta, escrava, mundana, sem reputação alguma", emendou Manoel Jorge Cação. "Antônia Barbosa é negra mundana pública e de má vida", fez eco Antônio Gonçalves da Rocha. "Antônia Barbosa é crioula negra, mundana e distraída", acrescentou José de Macedo. "Antônia Barbosa é preta dama de mau procedimento e costumes", realçou João Pinto Brandão. ${ }^{99}$

Não foi feita inquirição para ouvir sobre o crédito do padre denunciado, como de costume. O documento termina com a opinião de Gaspar Marques Vieira, tesoureiro-mor da Sé da Cidade da Bahia e comissário do Santo Ofício à frente daquela diligência. Ele também informou que o acusado se ausentara da capitania havia seis ou sete anos, constando que se encontrava na capitania do Espírito Santo, bispado do Rio de Janeiro, de onde era natural. O comissário deu crédito à denúncia da escrava Antônia Barbosa, afirmando que ela parecia dizer a verdade e que não sabia que fosse acostumada a levantar falso testemunho sobre pessoa alguma. No entanto, ele matizava negativamente sua fala sobre a escrava, dizendo que ela era "viciosa bastantemente no sexo, como (por pecados) o são aqui todas as crioulas e mulheres desta casta" ${ }^{100}$ Diferentemente de Inês Gomes, portanto, que ao "defeito de cor" se impunha uma virtude, a sua honestidade de mulher casada, no caso da escrava Antônia Barbosa a esse defeito juntava-se um pecado, a

\footnotetext{
99 ANTT, IL, Caderno de Solicitantes n. ${ }^{\circ}$ 19, fls. 583-5.

${ }^{100}$ ANTT, IL, Caderno de Solicitantes n. ${ }^{\circ}$ 19, fl. 585 (grifos meus).
} 
exacerbação da luxúria, do apetite sexual, que aparece como inerente à sua origem racial. Na consolidação do imaginário sobre a mulher, a colonização trouxe um elemento novo ao associar misoginia e racismo. A fala do comissário devassa bem o simbolismo sexual relacionado às mulheres de cor, que personificavam no imaginário as características da disponibilidade para o sexo, além da propensão para a mentira, como era o caso de Inês Gomes, herança da avó mulata.

O estereótipo da disponibilidade para o sexo, que aparecia como natural em se tratando de mulheres negras, não se aplicava somente àquelas nascidas no Brasil. Uma denúncia de solicitação protagonizada por Madalena da Silva, escrava do gentio da Mina, demonstra isso. Madalena era escrava de um familiar do Santo Ofício, Inácio Álvares, morador na Cidade da Bahia, na Praia. No ano de 1701, ela compareceu perante os comissários para denunciar o padre Eugênio Gomes por solicitá-la, havia cinco anos, em confissão sacramental que fazia na própria casa do padre, próxima a Igreja da Conceição. Era véspera da quinta-feira santa, à noite, e Madalena foi confessar-se junto com duas amigas, esperando comungar no dia seguinte. No momento da confissão, ajoelhada mesmo, a escrava ouviu do confessor a seguinte queixa: "Madalena, é possível que a tanto tempo te ando chamando e tu nunca queres vir? Porque me queres mal?". A esse apelo, Madalena respondeu ambiguamente: "Senhor Padre, eu me venho confessar, e não venho para isto, mas eu virei". Mais adiante, ela declara que o padre "antecedentemente a havia chamado várias vezes a sua casa para atos pecaminosos, porque entende não ter outro negócio com ele". ${ }^{101} \mathrm{Na}$ ambiguidade dessas suas respostas, surgem indícios de que ela mantinha algum tipo de relação com o confessor Eugênio Gomes.

De todo modo, os sacerdotes que acompanharam o depoimento consideraram que Madalena da Silva parecia dizer a verdade, e daí a diligência seguiu seu curso, sendo ouvidas testemunhas sobre seu crédito e sua reputação. Deixou-se, no entanto, de ouvir testemunhas sobre o padre acusado, como de praxe. Cinco testemunhas falaram sobre a ${ }^{101}$ ANTT, IL, Caderno do Promotor n. ${ }^{\circ} 81$, fl. 252, <http://digitarq.dgarq.gov.pt/
details?id=2318098>, acessado em 28 jul. 2012. 
escrava e eram homens supostamente brancos, como de costume, todos naturais do Reino, moradores também na Praia, quatro deles familiares do Santo Ofício. Eram, portanto, homens de algum destaque naquela sociedade. Os cinco enfatizaram seu comportamento e sua personalidade com excelentes adjetivos: "quieta, ladina", "tida e havida por sisuda e verdadeira", "preta sisuda, sujeita e de razão", "verdadeira e modesta nas mais ações". ${ }^{102}$

Mas a história de Madalena da Silva é mais um exemplo de como nem sempre a atribuição de crédito se fazia acompanhar de uma visão positiva sobre o comportamento. O crédito foi atribuído mais uma vez como uma exceção. Nesse sentido, no tocante à reputação moral, à conduta sexual, a fala dos homens expressou mais uma vez a condenação. Moralistas, eles não se refrearam no julgamento de sua vida. "Madalena é uma mulher preta meretriz pública de pouca reputação", argumentou o familiar Miguel Vareiro, natural do Porto. "Madalena é preta meretriz como são todas dessa qualidade, e sem reputação", enfatizou o também familiar Antônio Álvares Seixas, natural de Viana. "Madalena é uma mulher mundana como costumam ser todas desta qualidade, desta terra, sem reputação", reforçou André Moreira Coutinho. "Madalena é uma mulher mundana pública, como o são todas desta qualidade neste estado", afirmou Nicolau Lopes Fiúza, também de Viana. "Madalena é uma mulher escrava e meretriz pública, sem reputação, como são todas as criaturas desta qualidade neste estado", acrescentou o familiar Manuel Pinto de Carvalho, natural de Guimarães. ${ }^{103}$

A apreciação moralista sobre Madalena da Silva demonstra, mais uma vez, como as relações na sociedade colonial foram temperadas pela misoginia e pelo racismo. Construíram-se, nesse processo, noções estereotipadas sobre a conduta sexual feminina que colocavam naturalmente em dúvida a honra e a reputação de índias e negras, particularmente das escravas negras e suas descendentes. Os arroubos de sedução dos padres no refúgio do confessionário na Bahia, denunciados nas primeiras décadas do século XVIII, sugerem que esses homens setecentistas

${ }_{102}^{102}$ ANTT, IL, Caderno do Promotor n. ${ }^{\circ}$ 81, fls. 254-6. 
carregavam essa influência. Muitos convites e assédios dirigiam-se àquelas oriundas do mundo da escravidão ou com ele relacionadas. Ainda que os exemplos aqui fornecidos não formem uma estatística, é possível deduzir-se que não foi grande o número de mulheres assediadas qualificadas como brancas ou que, pelo menos, foram poucas as mulheres brancas que tomaram a atitude de denunciar. É verdade que bem menor era o número delas na sociedade colonial. Apenas em um dos relatos aqui analisados, não houve menção à cor da denunciante, o que levanta a suposição de que ela poderia ser branca ou tida com tal. As demais foram classificadas como negras, pardas, mulatas, mestiças.

Em seu estudo pioneiro, Lana Lima demonstra como a cor e a condição social das mulheres também tinham influência nas próprias estratégias de solicitação postas em prática pelos religiosos da Colônia. Quando as escolhidas eram brancas, ou assim consideradas, havia algum cuidado no discurso amoroso, nas "palavras amatórias", para usar uma expressão da época. Os galanteios deixavam escapar, em alguns casos, sentimentos mais complexos que o desejo carnal puro e imediato. Mesmo havendo exceções, os convites diretos para a prática sexual, sem subterfúgios ou gentilezas, eram dirigidos preferencialmente às não brancas, sobretudo às escravas e forras. A misoginia racista da sociedade colonial as classificava como mulheres fáceis, alvos naturais de investidas sexuais. ${ }^{104}$

Parece evidente, pelos casos estudados, que, no início do período setecentista, o fenótipo já se tornara um indicador importante de qualificação social. Ainda se está longe do racismo vigente no século XIX, como argumenta Silvia Lara, "que associava a cor preta ou mulata a uma origem (africana) considerada inescapavelmente inferior ou que adotava critérios científicos para diferenciar e hierarquizar as "raças". ${ }^{105}$ Na sociedade colonial, a associação entre cor e condição social não era sempre automática e poderia estar ligada a uma série de fatores ou percepções. Mas ela funcionava como meio de demarcar diferenças e permitir discriminações. A cor da pele poderia estar associada à condição

\footnotetext{
${ }^{104}$ Lima, “A confissão pelo avesso", p. 595.
}

${ }^{105}$ Lara, Fragmentos setecentistas, p. 141. 
que separava a liberdade da escravidão e era lida como uma das muitas marcas simbólicas da distinção social. ${ }^{106}$ Nos documentos relativos ao crime de solicitação, aparecem pistas importantes de como a associação entre cor e condição social, aliada à questão da moral sexual e dos estereótipos de gênero, servia de esteio para a desqualificação feminina.

Texto recebido em 8 de setembro de 2012 e aprovado em 22 de fevereiro de 2013.

\begin{abstract}
Resumo
$\mathrm{O}$ artigo analisa os desdobramentos de um tipo de delito perseguido pela Inquisição portuguesa: o crime de solicitação, quando os padres confessores incorriam no assédio às suas filhas espirituais no confessionário ou em torno do sacramento da Confissão. A partir de denúncias feitas ao Santo Ofício, discute a teia de misoginia e racismo que, por vezes, transparecia nas palavras dos homens chamados para testemunhar sobre o crédito, o comportamento e a reputação das mulheres solicitadas. Busca analisar ainda como, no contexto do colonialismo escravista, se difundiu uma visão estigmatizada sobre a conduta sexual das mulheres negras e suas descendentes.
\end{abstract}

Palavras-chave: inquisição; solicitação; mulheres; misoginia; racismo.

\begin{abstract}
This paper analyses the ramifications of a category of crime prosecuted by the Portuguese Inquisition: the crime of solicitation, when priests incurred the harassment of their spiritual daughters in the confessional or throughout the sacrament of confession. It discusses, based on denunciations made to the Holy Office, the web of misogyny and racism that, at times, would appear evident in the words of the men called to testify about the credit, behavior and reputation of those women solicited. The text also searches to analyse how, in the context of the colonial slave system, a stigmatized vision regarding the sexual behavior of black women and their descendants was diffused.
\end{abstract}

Keywords: inquisition; solicitation; women; misogyny; racism.

\footnotetext{
${ }^{106}$ Lara, Fragmentos setecentistas, p. 144.
} 
